Prepared in cooperation with the

Vermont Department of Environmental Conservation

\title{
Use of Acoustic Backscatter to Estimate Continuous Suspended Sediment and Phosphorus Concentrations in the Barton River, Northern Vermont, 2010-2013
}

Open-File Report 2014-1184 



\section{Use of Acoustic Backscatter to Estimate Continuous Suspended Sediment and Phosphorus Concentrations in the Barton River, Northern Vermont, 2010-2013}

By Laura Medalie, Ann T. Chalmers, Richard G. Kiah, and Benjamin Copans

Prepared in cooperation with the

Vermont Department of Environmental Conservation

Open-File Report 2014-1184 


\title{
U.S. Department of the Interior SALLY JEWELL, Secretary
}

\section{U.S. Geological Survey Suzette M. Kimball, Acting Director}

\author{
U.S. Geological Survey, Reston, Virginia: 2014
}

For more information on the USGS - the Federal source for science about the Earth, its natural and living resources, natural hazards, and the environment, visit http://www.usgs.gov or call 1-888-ASK-USGS/.

For an overview of USGS information products, including maps, imagery, and publications, visit http://www.usgs.gov/pubprod/

To order this and other USGS information products, visit http://store.usgs.gov/

Any use of trade, firm, or product names is for descriptive purposes only and does not imply endorsement by the U.S. Government.

Although this information product, for the most part, is in the public domain, it also may contain copyrighted materials as noted in the text. Permission to reproduce copyrighted items must be secured from the copyright owner.

Suggested citation:

Medalie, Laura, Chalmers, A.T., Kiah, R.G., and Copans, Benjamin, 2014, Use of acoustic backscatter to estimate continuous suspended sediment and phosphorus concentrations in the Barton River, northern Vermont, 2010-2013: U.S. Geological Survey Open-File Report 2014-1184, 29 p., 4 appendixes, http://dx.doi.org/10.3133/ofr20141184. 


\section{Acknowledgments}

The authors would like to thank Jason Jarvis, of the U.S. Geological Survey, for his technical assistance with sediment, phosphorus, and streamflow data collection, the Vermont Department of Environmental Conservation Laboratory for analyzing the phosphorus samples, and Mark Landers, Elizabeth Nystrom, and Jamie Shanley, of the U.S. Geological Survey, for their thoughtful technical reviews. 



\section{Contents}

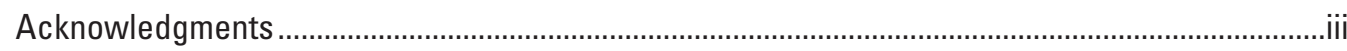

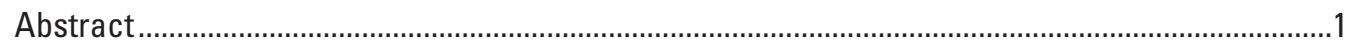

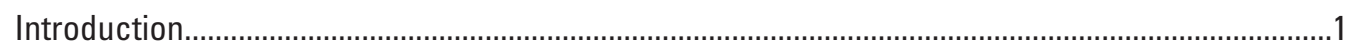

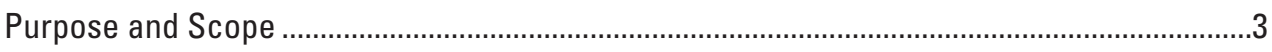

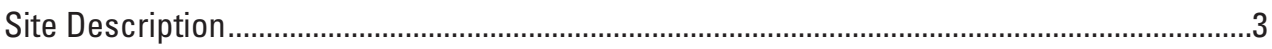

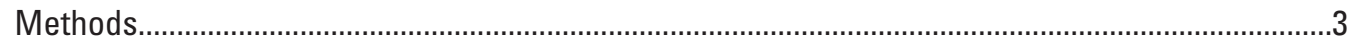

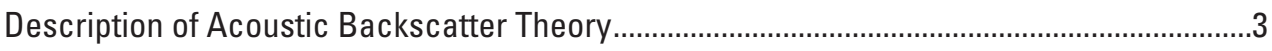

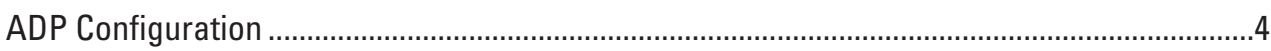

Collection and Analysis of Water Samples ...........................................................................

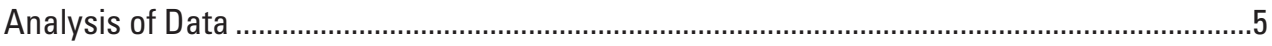

Results of Study.

Particle-Size Distribution.......................................................................................................6

Relations Between Sand- and Fine-Grained Sediments to Backscatter and Attenuation ......6

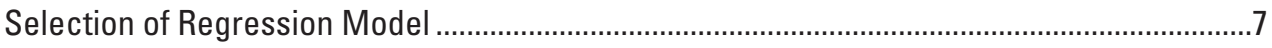

Estimation of Constituent Concentrations ............................................................................

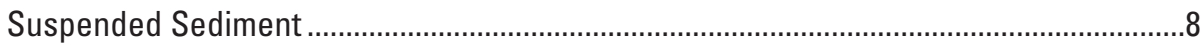

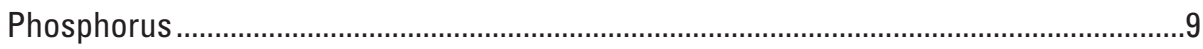

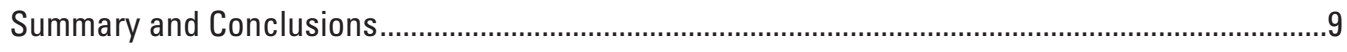

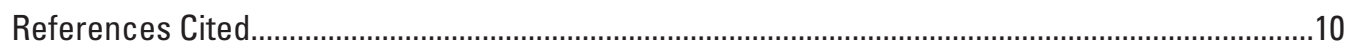

Appendix 1. Input to Surrogate Analysis and Index Developer Model Program-

15-Minute Data on Water Depth and Temperature ............................................................29

Appendix 2. Input to Surrogate Analysis and Index Developer Model Program-

15-Minute Data on Measured Backscatter .....................................................................29

Appendix 3. Calibration Dataset and Model Results for Streamgage 04296280_

Barton River Near Coventry—Suspended-Sediment Concentration...................................29

Appendix 4. Calibration Dataset and Model Results for Streamgage 04296280_-

Barton River Near Coventry-Total Phosphorus Concentration ..........................................29

\section{Figures}

1. Map showing the location of the Barton River study site near Coventry, Vermont, and land use in the watershed

2. Photograph of the acoustic Doppler profiler and staff plate mounted on the right bank of the Barton River in Coventry, Vermont.

3. Schematic diagram of the acoustic Doppler profiler used at the Barton River near Coventry, Vermont

4. Plot of concentrations of phosphorus as a function of concentrations of suspended sediment for water samples from the Barton River near Coventry, Vermont, 2010 through 2013

5. Graphs showing hysteresis in suspended-sediment concentration (SSC) as a function of discharge and sediment-corrected backscatter (SCB) for a May 2013 storm at the Barton River near Coventry, Vermont, shown as $A$, time-series plot of SCB, SSC, and discharge; $B$, SSC/discharge hysteresis; and C, SSC/SCB hysteresis ...17 
6. Graph showing concentrations of fine as a function of total suspended sediment for samples collected before and after tropical storm Irene (August 28-29, 2011), from the Barton River near Coventry, Vermont........................................................................18

7. Plots showing best fit regression lines of suspended sediment as a function of sediment-corrected backscatter for the Barton River near Coventry, Vermont.

8. Plot showing concentrations of fine-grained sediment as a function of sedimentdriven acoustic attenuation for samples collected during rising and falling or stable stages of the hydrograph at the Barton River near Coventry, Vermont, from 2010 through 2013.

9. Graph showing theoretical relations for backscatter and attenuation for a given suspended-sediment concentration as a function of particle size (at 1-megahertz frequency).

10. Graph showing comparison of measured and estimated concentrations of suspended sediment for samples from the Barton River near Coventry, Vermont, from August 2010 through May 2013.

11. Graph showing sediment-corrected backscatter, discharge, and measured and estimated suspended-sediment concentrations in samples from the Barton River near Coventry, Vermont, from April 16 through May 31, 2013

12. Graph showing comparison of measured and estimated concentrations of phosphorus for samples from the Barton River near Coventry, Vermont, from August 2010 through May 2013.

13. Graph showing sediment-corrected backscatter, discharge, and measured and estimated concentrations of total phosphorus from the Barton River near Coventry, Vermont, from April 16 through May 31, 2013.

\section{Tables}

1. Streamflow and concentrations of suspended sediment and phosphorus in water samples from the Barton River near Coventry, Vermont, from 2010 through 2013

2. Coefficients of determination for linear regressions between concentrations of suspended sediment, fines, and sands; and discharge, sediment attenuation, backscatter, and total phosphorus for the Barton River near Coventry, Vermont, from 2010 through 2013

3. Linear regression models and metrics to assess estimated concentrations of suspended sediment and total phosphorus from acoustic surrogates and discharge in the Barton River, Vermont. 


\section{Conversion Factors, Datum, and Abbreviations}

Inch/Pound to SI

\begin{tabular}{lcl}
\hline \multicolumn{1}{c}{ Multiply } & By & \multicolumn{1}{c}{ To obtain } \\
\hline inch (in.) & Length & \\
foot (ft) & 25.4 & millimeter $(\mathrm{mm})$ \\
mile (mi) & 0.3048 & meter $(\mathrm{m})$ \\
\hline & 1.609 & kilometer $(\mathrm{km})$ \\
\hline square mile $\left(\mathrm{mi}^{2}\right)$ & Area & \\
\hline & 2.590 & square kilometer $\left(\mathrm{km}^{2}\right)$ \\
\hline foot per second $(\mathrm{ft} / \mathrm{s})$ & Flow rate & \\
cubic foot per second $\left(\mathrm{ft}^{3} / \mathrm{s}\right)$ & 0.3048 & meter per second $(\mathrm{m} / \mathrm{s})$ \\
\hline
\end{tabular}

Temperature in degrees Fahrenheit $\left({ }^{\circ} \mathrm{F}\right)$ may be converted to degrees Celsius $\left({ }^{\circ} \mathrm{C}\right)$ as follows: ${ }^{\circ} \mathrm{C}=\left({ }^{\circ} \mathrm{F}-32\right) / 1.8$

Vertical coordinate information is referenced to the North American Vertical Datum of 1988 (NAVD 88).

Concentrations of chemical constituents in water are given either in milligrams per liter (mg/L) or micrograms per liter $(\mu \mathrm{g} / \mathrm{L})$.

Elevation, as used in this report, refers to distance above the vertical datum.

\section{Abbreviations}

$\begin{array}{ll}\text { ADP } & \text { acoustic Doppler profiler } \\ \mathrm{dB} / \mathrm{m} & \text { decibels per meter } \\ \text { MB } & \text { measured backscatter } \\ \text { PSD } & \text { particle-size distribution } \\ \text { RMSE } & \text { root mean squared error } \\ \text { SAID } & \text { Surrogate Analysis and Index Developer tool } \\ \text { SCB } & \text { sediment-corrected backscatter } \\ \text { SNR } & \text { signal-to-noise ratio } \\ \text { SSC } & \text { suspended-sediment concentration } \\ \text { TP } & \text { total phosphorus } \\ \text { USGS } & \text { U.S. Geological Survey } \\ \text { WCB } & \text { water-corrected backscatter }\end{array}$





\title{
Use of Acoustic Backscatter to Estimate Continuous Suspended Sediment and Phosphorus Concentrations in the Barton River, Northern Vermont, 2010-2013
}

\author{
By Laura Medalie, ${ }^{1}$ Ann T. Chalmers, ${ }^{1}$ Richard G. Kiah,, and Benjamin Copans ${ }^{2}$
}

\begin{abstract}
The U.S. Geological Survey, in cooperation with the Vermont Department of Environmental Conservation, investigated the use of acoustic backscatter to estimate concentrations of suspended sediment and total phosphorus at the Barton River near Coventry, Vermont. The hypothesis was that acoustic backscatter - the reflection of sound waves off objects back to the source from which they came - measured by an acoustic Doppler profiler (ADP) and recorded as ancillary data for the calculation of discharge, also could be used to generate a continuous concentration record of suspended sediment and phosphorus at the streamgage, thereby deriving added value from the instrument. Suspended-sediment and phosphorus concentrations are of particular interest in Vermont, where impairment of surface waters by suspended sediments and phosphorus is a major concern.

Regression models for estimating suspended-sediment concentrations (SSCs) and total phosphorus concentrations evaluated several independent variables: measured backscatter (MB), water-corrected backscatter (WCB), sediment-corrected backscatter (SCB), discharge, fluid-absorption coefficient, sediment-driven acoustic attenuation coefficient, and discharge hysteresis. The best regression equations for estimating SSC used backscatter as the predictor, reflecting the direct relation between acoustic backscatter and SSC. Backscatter was a better predictor of SSC than discharge in part because hysteresis between SSC and backscatter was less than for SSC and discharge. All three backscatter variables-MB, WCB, and SCBperformed equally as predictors of SSC and phosphorus concentrations at the Barton River site. The similar abilities to predict SSC among backscatter terms may partially be attributed to the low values and narrow range of the sediment-driven acoustic attenuation in the Barton River. The regression based on SCB was selected for estimating SSC because it removes potential bias caused by attenuation and temperature fluctuations. The best regression model for estimating phosphorus concentrations included terms for discharge and discharge hysteresis. The finding that discharge hysteresis was a significant predictor of phosphorus concentrations might be related to preferential sorption of phosphorus to fine-grained sediments, which have been found to be particularly sensitive to hysteresis. Regression models designed to estimate phosphorus concentrations had less predictive power than the models for SSCs.

Data from the Barton River did not fully support one of the study's hypotheses - that backscatter is mostly caused by sands, and attenuation is mostly caused by fines. Sands, fines, and total SSCs in the Barton River all related better to backscatter than to sediment-driven acoustic attenuation. The weak relation between SSC and sediment-driven acoustic attenuation may be related to the low values and narrow range of SSCs and sediment attenuations observed at Barton River. A weak relation between SSC and sediment-driven acoustic attenuation also suggests that the diameters of the fine-sized suspended sediments in the Barton River may be predominantly greater than 20 micrometers $(\mu \mathrm{m})$. Long-term changes in the particle-size distribution (PSD) were not observed in Barton River; however, some degree of within-storm changes in sediment source and possibly PSD were inferred from the hysteresis between SSC and SCB.
\end{abstract}

\section{Introduction}

Surface waters on Vermont's 2012 Clean Water Act section 303(d) list include 26 water bodies impaired by sediment deposition and 23 water bodies impaired by phosphorus or nutrients (Vermont Department of Environmental Conservation, 2012). One of two lakes on the 303(d) list with a phosphorus impairment is Lake Memphremagog, the receiving water body for the Barton River, in northern Vermont. The State's management strategy for waters that are impaired includes collection

\footnotetext{
${ }^{1}$ U.S. Geological Survey

${ }^{2}$ Vermont Department of Environmental Conservation
} 
of water-quality data to fully assess the effects of individual permit decisions and to support the State's methodologies for compliance with regulatory programs (Vermont Department of Environmental Conservation, 2013).

The collection of water samples for the analysis of suspended-sediment concentration (SSC) or phosphorus concentration requires an investment of money and time for equipment, sample collection, laboratory analysis, and data interpretation. Even programs with sufficient resources to collect and analyze many samples over long time periods will produce records with some data gaps. Comprehensive profiles of stream-water quality during storm events are particularly difficult to capture and usually involve automated samplers that require effort for setup and troubleshooting. Yet runoff from large storms can transport large percentages of the total annual loads of suspended sediment or phosphorus (Hirsch, 2012), which therefore are important to characterize. The pattern in Vermont and New England of increasing storm flows in recent decades (Hodgkins and Dudley, 2011) reinforces the need for understanding suspended-sediment and phosphorus loading during storms.

To address the need for continuous records of water-quality data, scientists typically develop equations relating the continuous measurement of a surrogate parameter, such as streamflow or turbidity, to discrete measurements of the parameter of interest (Christensen and others, 2000). All 12 approved Total Maximum Daily Load documents for streams in Vermont since 2007 list biological or sediment impairment as the pollutant of concern and specify using stormwater-runoff volume or discharge as the surrogate measurement needed to address reductions (U.S. Environmental Protection Agency, 2013).

Acoustic Doppler profilers (ADPs) have become a frequently used tool for stream velocity and streamflow measurements (Mueller and others, 2013). The use of ADP backscatter data as a surrogate for the computation of continuous SSC is an ongoing topic of research by the U.S. Geological Survey (USGS) and others (Gray and Gartner, 2009; Landers and others, 2012; Wood, 2014). Backscatter is the reflection of sound waves off objects back to the source from which they came. Using ADP backscatter to estimate SSC has a number of advantages: (1) ADP measurements are made across the stream width rather than at a single point, (2) ADPs are not sensitive to biofouling, and (3) there is added value because backscatter can be used to assist in the computation of discharge (Gray and Gartner, 2009).

ADPs measure stream velocity by transmitting an acoustic pulse and recording the sound scattered back from suspended particles in the water. If the particles are moving along the axis of the acoustic beam, then the returned sound from different points along the beam will be shifted in frequency (Doppler shift). ADPs use this Doppler frequency shift and the speed of sound in water to compute velocity in each beam. Two or more beams are used to obtain two-dimensional velocity. In addition to measurements directly used for water velocity, ADPs measure and record the amplitude of the returned signal or backscatter. The signal amplitude relates to the concentration of suspended particles scattering sound back to the instrument (Wood, 2014); therefore, backscatter is directly related to SSC, whereas discharge, another potential surrogate for SSC, has no direct relation.

Most methods used to convert acoustic backscatter to SSC can be traced back to an application in sonar (Urick, 1975). These methods require adjusting the measured backscatter (MB) for factors other than SSC to isolate the backscatter-to-SSC relation. The evolution of enhancements to the use of acoustic backscatter as a surrogate for SSC and a description of its limitations in estimating fluvial SSC has been summarized in the literature (Gray and Gartner, 2009; Landers, 2010; Gray and Landers, 2014). A potential refinement to the postprocessing analysis for acoustic backscatter is the accounting for acoustic attenuation caused by sediment by using the slope of the loss of signal through the lateral stream profile (Topping and others, 2007). Accounting for acoustic attenuation becomes more important in fluvial systems with high SSCs that are dominated by fine-sized particles (Flammer, 1962).

Both particle size and SSC influence backscatter amplitude. Estimating SSC can be confounded on highly regulated rivers with bimodal sediment-supply regimes where particle-size distributions (PSD) change extremely rapidly. Topping and others (2007) developed empirical equations based on the relations between backscatter, sediment attenuation, SSC and PSD to discriminate silt-and-clay (called fines in this report) from suspended sand. Researchers are interested in testing the application of their empirically based equations on other areas and under different conditions (Wright and others, 2010). The specific questions to test for general applicability are whether, over a range of conditions, attenuation is mostly caused by fines, and backscatter is mostly caused by sand (Wright and others, 2010).

In addition, considerable effort has been spent investigating the use of surrogates to estimate phosphorus concentrations in stream water. Surrogates for SSCs, such as optical turbidity, have been used successfully to estimate phosphorus concentrations (Grayson and others, 1996; Christensen and others, 2000; Rasmussen and others, 2009). The relation with turbidity works because there is a strong link between transport of total phosphorus and suspended sediment (Mueller and Spahr, 2006). Whereas we are not aware of published work on the subject of using acoustic backscatter measured by an ADP to estimate total phosphorus, a joint University of Vermont/USGS study in northern Vermont is currently (2013) underway to investigate the topic (William "Breck" Bowden, University of Vermont, written commun., 2013).

A fixed side-looker ADP was installed in July of 2010 by the USGS at the Barton River near the Coventry, Vermont, streamgage (04296280) to measure discharge. This instrument is better able to overcome effects of backwater from Lake Memphremagog than methods based on typical stage-discharge ratings (Levesque and Oberg, 2012). At approximately the same time, the USGS, in cooperation with the Vermont Department of Environmental Conservation, began an auxiliary study at this streamgage to investigate the use of acoustic backscatter as a surrogate for SSC and total phosphorus concentration. The 
hypothesis was that acoustic backscatter, measured by the ADP and recorded as ancillary data for the discharge calculation, also could be used to generate continuous suspended-sediment and phosphorus records at the streamgage, potentially deriving added value from the instrument.

\section{Purpose and Scope}

The primary objective of this report was to summarize results on the use of acoustic backscatter generated by the ADP at the Barton River near Coventry, Vt., streamgage to calculate a continuous record of SSCs and phosphorus concentrations from August 31, 2010, through May 31, 2013. Estimates of continuous phosphorus concentrations are of particular interest in Vermont, where impairment of surface waters by suspended sediments and phosphorus is a major concern. A secondary objective was to establish datasets from a North Atlantic test site and examine theoretically derived relations of attenuation and backscatter to fine- and sand-sized sediments (Topping and others, 2007; Wright and others, 2010).

\section{Site Description}

The Barton River study site, located at streamgage 04296280, drains a 401-square-kilometer $\left(\mathrm{km}^{2}\right)$ area in northern Vermont. The streamgage is about 7.2 kilometers $(\mathrm{km})$ south of Newport City and about $15 \mathrm{~km}$ south of the Canadian border (fig. 1). The Barton River's final reach between the streamgage and the southern end of Lake Memphremagog winds through the protected State-owned South Bay Wildlife Management Area. This forested swamp covers about 500 acres $\left(2 \mathrm{~km}^{2}\right)$ of red maple and northern white cedar and has rare or endangered communities of creeping sedge, slender cottongrass, and bur-reed (Vermont Agency of Natural Resources, 2006). Several of the lakes in the watershed are premier cold water fisheries that support indigenous and wild populations of lake trout, wild and stocked populations of rainbow trout, and stocked landlocked Atlantic salmon. The Barton River supports populations of wild brook trout, brown trout, and rainbow trout (Vermont Agency of Natural Resources, 2006).

About 69 percent of the watershed is forested, 17 percent is agricultural, 6 percent is developed, 4 percent is water, and 2 percent each is wetlands and shrub or scrub (not differentiated from forested land in fig. 1) (Homer and others, 2007). Most of the agricultural and developed land is along the river corridor. The bedrock and soils are rich in calcium (Thompson and Sorenson, 2000). A recent modeling study in a nearby northern Vermont watershed found that about 60 percent of the sediment and phosphorus loads came from upland sources, and about 40 percent were attributable to stream bank erosion (Winchell and others, 2011).

\section{Methods}

Acoustic backscatter theory, ADP instrument configuration, SSC and phosphorus sample collection and analysis, and the analysis of data using linear regression models are described in this section. Methods of measuring stream discharge are published as part of the USGS Annual Water Data Report and may be obtained at http://wdr.water.usgs.gov/data/.

\section{Description of Acoustic Backscatter Theory}

The theory and methods for establishing a relation between acoustic backscatter and SSC are described in detail in the literature (Topping and others, 2007; Gray and Gartner, 2009; Landers, 2010; Wright and others, 2010; Gray and Landers, 2014). In essence, the amplitude of backscatter is physically related to SSC as well as to other factors that can be accounted for to isolate the SSC-to-backscatter relation. SSC and backscatter are theoretically related as:

$$
\log _{10}(S S C)=0.1(S C B)+b
$$

where
$b \quad$ is a constant specific to the ADP instrument and the site; and
$S C B \quad$ is sediment-corrected backscatter (Gartner, 2004; Thorne and Hanes, 2002).

Based on the assumption of a strong relation between total phosphorus and SSC in streams, total phosphorus concentration $(T P)$ was estimated by formulating equation 2 , as follows: 


$$
\log _{10}(T P)=0.1(S C B)+b,
$$

where total phosphorus is substituted for the suspended-sediment term of equation 1 . The extent to which this modification of equation 1 yields meaningful results is explored later in this report.

The ADP records backscatter as the signal-to-noise ratio (SNR). The SNR is the raw amplitude of the backscatter signal minus acoustic noise (also measured over each averaging interval) that may result from instrument or environmental sources. The measured backscatter (MB) is taken from the SNR and converted to decibels by a conversion constant ( 0.43 for the Sontek SL used in this study based on the manufacturer recommendation). The MB decreases at successively greater distances along the transmission beam because of acoustic signal spreading and attenuation as a result of water and sediment properties. These properties are influenced by temperature and particle-size fluctuations and may vary in time and space. Water attenuation results from fluid absorption of sound. Sediment-driven acoustic attenuation results from sound being scattered away from the transducer and (or) absorbed by particles (Gartner, 2004).

Two successive compensations can be made to MB for signal losses due to the water and sediment. First, MB can be corrected for spreading and attenuation by water, resulting in WCB (water-corrected backscatter), calculated as follows:

$$
W C B=M B+20 \log _{10}(R)+2 \alpha_{w} R,
$$

where

$$
\begin{array}{ll}
R & \text { is the distance [in meters }(\mathrm{m})] \text { along the transmission beam from the ADP; and } \\
\alpha_{w} & \text { is the fluid absorption coefficient [in decibels per meter }(\mathrm{dB} / \mathrm{m}) \text { ], which is a function of temperature and the } \\
\text { instrument. }
\end{array}
$$

The calculation of WCB builds on MB (Topping and others, 2007; Landers, 2010; Wright and others, 2010; Gray and Landers, 2014): Second, WCB can be corrected for sound attenuation by the sediment, resulting in SCB (sediment-corrected backscatter). The SCB is the acoustic signal that is driven by changes in SSC, after accounting for other factors. SCB is calculated from WCB as follows:

$$
\begin{aligned}
& S C B=W C B+2 \alpha_{s} R, \text { and } \\
& \alpha_{s}=\frac{-1 / 2 d(W C B)}{d R} .
\end{aligned}
$$

The variable $\alpha_{s}$ is the sediment-driven acoustic attenuation coefficient, which is calculated, as shown in equation 5, from the slope of the linear regression between $W C B$ and the distance along the transmission beam. This definition of the sediment-driven acoustic attenuation coefficient depends on the assumption that the distribution of SSC and particle size does not vary significantly across the lateral profile of the stream.

\section{ADP Configuration}

Methods and principles of installation and configuration of ADPs for velocity measurements described in detail in Levesque and Oberg (2012) can be applied without modification to installations for the determination of sediment surrogates. The ADP (fig. 2) deployed at the Barton River near Coventry, Vt., is mounted at a fixed location on the right (east) bank about $1.5 \mathrm{~m}$ above the river bottom at an elevation of about $207.2 \mathrm{~m}$ above North American Vertical Datum of 1988 (NAVD 88). The side-looking ADP transmits an acoustic signal horizontally through the water along two beams at a frequency of 1.5 megahertz (MHz). The instrument used for this study is a Sontek Argonaut-SL (http://www.sontek.com/) serial number E3132, which has two horizontal beams oriented 50 degrees apart and a vertical beam used to adjust discharge for ice conditions (fig. 3). The ADP records velocity and acoustic backscatter from the acoustic beam of each transducer.

The Sontek Argonaut SL can be configured with up to 10 cells but can transmit only 5 cells via the SDI-12 protocols used at this streamgage. Thus the Sontek Argonaut SL was configured for 5 separate cells along the beam path, each of which measures $1.22 \mathrm{~m}$ of the beam path for a total profile of $6.1 \mathrm{~m}$ (fig. 3). The measured profile extends from $0.5 \mathrm{~m}$ in front of the transducer face (the blanking distance) to $6.6 \mathrm{~m}$. ADP data (water temperature, pressure, velocity, SNR, and discharge) are recorded on a 15-minute measurement interval and represent an average of continuous readings observed over a 5-minute span. 
During routine site visits, the instrument is inspected for biofouling and cleaned as needed. Biofouling was monitored through the collection of beam checks. No reduction in signal strength was noted during evaluation of beam checks.

\section{Collection and Analysis of Water Samples}

Concurrent measurements of acoustic backscatter and representative SSC and phosphorus samples from the Barton River were a critical element of data collection for this study. Water samples were collected at the Barton River streamgage over a wide range of discharge conditions from August 31, 2010, through May 31, 2013 (table 1). Water samples were collected from the upstream side of the bridge over Coventry Station Road (fig. 1 shows the downstream bridge face) by using a handheld DH-59 sampler and following standard USGS protocols (Edwards and Glysson, 1999; U.S. Geological Survey, 2006). When the velocity of the Barton River was greater than 1.5 feet per second (ft/s) $[0.46$ meters per second $(\mathrm{m} / \mathrm{s})]$, the equal-widthincrement protocol was followed, whereby water samples were collected from multiple (10) verticals. When the velocity was less than $1.5 \mathrm{ft} / \mathrm{s}$, a single vertical was sampled at the approximate midflow location in the river. The single vertical is considered reasonable for this stream for velocities less than $1.5 \mathrm{ft} / \mathrm{s}$ because these low velocities do not transport any significant fraction of sand-size material, and the fine-grained material is well mixed across the channel width. All samples were composited into a churn splitter, from which subsamples were drawn for SSC and phosphorus-concentration analysis.

Forty-eight water samples were analyzed for SSC at the USGS Kentucky Sediment Laboratory (Shreve and Downs, 2005). Three of these SSC samples were not used for analysis in this study because they did not have concurrent measurements of backscatter. Forty-four of the SSC samples were analyzed for the percentage of the mass of particles that were less than 62.5 micrometers $(\mu \mathrm{m})$ in diameter (fine fraction), and 7 samples were analyzed for five additional sediment-size classifications that ranged between fines and coarse sand [greater than $62.5 \mu \mathrm{m}$ and less than 1 millimeter $(\mathrm{mm})$ ].

Fifty-five water samples were analyzed for total phosphorus at the Vermont Department of Environmental Conservation Laboratory in Burlington (Needham and Russo, 2013). Eight of these total phosphorus samples were not used for analysis in this study because they did not have concurrent measurements of backscatter. Throughout this report, use of the term "phosphorus" means "total phosphorus."

\section{Analysis of Data}

The ADP configuration on the Barton River divides the acoustic signal into five lateral cells, with the first cell closest to the instrument and the fifth farthest away. The MB values from the two beams, for each numbered cell, were averaged for each measurement. Five values of backscatter, one for each cell, were averaged over 5 minutes and recorded every 15 minutes by the data logger. The variable $R$ in equations 3 through 5 is the midpoint distance of each cell from the instrument. For the 15 -minute recorded data, equations 3 through 5 were applied five times for each cell's measurement of backscatter. Because there was little variation among the backscatter results from the five cells, the mean backscatter for the 5 cells was used in regression equations for predicting SSC and phosphorus.

A USGS computer program, the Surrogate Analysis and Index Developer (SAID) tool (version 20131101; Marian Domanski and Timothy Straub, U.S. Geological Survey, written commun., November 1, 2013) was developed to automate the data processing and computational procedures for this method. SAID was used to compute the acoustic parameters and to develop linear regression models to estimate SSCs and phosphorus concentrations from several different independent variables. Input datasets of concurrent ADP and sample concentrations for SAID are in appendixes 1 and 2, and program output is in appendixes 3 and 4. Output from SAID included a variety of statistical and graphical tools that enabled the user to determine model validity and to make comparisons among regression models. SAID also identifies outliers by producing a tabular output of leverage and influence statistics (Helsel and Hirsch, 2002) for every observation and provides the ability to evaluate and remove outliers from model calculations.

The last step in data analysis was undertaken to prevent potential retransformation bias that could underestimate results when transforming logarithms of estimated concentrations back to original concentration units (Helsel and Hirsch, 2002). A nonparametric smearing factor (Duan, 1983) was used to correct for this potential bias.

\section{Results of Study}

Table 1 summarizes instantaneous discharge and concentrations of suspended sediment and phosphorus for water collected from the Barton River between August 31, 2010, and May 31, 2013. Discharge over the sample period ranged from 28 to 6,070 cubic feet per second ( $\left.\mathrm{ft}^{3} / \mathrm{s}\right)$, compared to instantaneous discharge during sample collections of 39 to $4,550 \mathrm{ft}^{3} / \mathrm{s}$. 
Fine-grained suspended sediment measured in samples ranged from 53 to 100 percent of the total SSC during the sampling period and had a median of 80 percent. Measured SSCs ranged from 2 to 413 milligrams per liter (mg/L) with a median value of $71 \mathrm{mg} / \mathrm{L}$, and measured phosphorus concentrations ranged from 12 to 292 micrograms per liter $(\mu \mathrm{g} / \mathrm{L})$ with a median value of $55 \mu \mathrm{g} / \mathrm{L}$.

A strong relation $\left(\mathrm{r}^{2}=0.83\right)$ was observed between the logarithms of SSC and phosphorus for samples from the Barton River (fig. 4). Significant positive relations between phosphorus and SSC have been found in many studies (Mueller and Spahr, 2006) because phosphorus typically is predominantly associated with the particulate phase, especially during high-flow and high-SSC events (Hirsch, 2012). Phosphorus had a stronger regression relation to fine-grained suspended sediment $\left(\mathrm{r}^{2}=0.80\right)$ than to sands, $\left(r^{2}=0.55\right.$; table 2$)$ suggesting preferential sorption of phosphorus to fine-grained suspended sediment. Preferential sorption of phosphorus to fine-grained suspended sediment most likely is caused by the greater surface area of the fine-grained suspended sediment.

SSC had a weak log-linear relation with discharge $\left(r^{2}=0.27\right.$; table 2$)$ at the Barton River. Hysteresis in the relation of SSC to discharge was the apparent cause for this weak relation. Using discharge as a surrogate for SSC would predict the same SSC on rising and falling limbs of the hydrograph, whereas actual sediment concentrations can vary greatly (Wood, 2014). The time series plot of the May 21-26, 2013 storm (fig. 5A) graphically illustrates SSC at the Barton River peaks before discharge, resulting in higher SSC at a given discharge on the rising limb of the hydrograph than at the same discharge on the falling limb. The resulting clockwise SSC-discharge (SSC-Q) hysteresis (fig. 5B) is most likely a result of flushing and depletion of sediment sources from the channel prior to the peak discharge (Landers and Sturm, 2013). The weak relation between SSC and discharge provided strong motivation for investigating the use of a different surrogate (that is acoustic) for estimating SSC.

\section{Particle-Size Distribution}

The determination of changes in the particle-size distribution (PSD) is important in interpreting acoustic surrogates because of the inability to differentiate between changes in SSC and changes in PSD in a single-frequency instrument (Gray and Gartner, 2009). PSD can change within a single storm or over longer periods of time. To evaluate long-term (greater than 1 year) changes in PSD, PSD was compared before and after tropical storm Irene (U.S. Geological Survey, 2011), a storm of unusual magnitude that occurred approximately midway through the study period on August 28-29, 2011. Flooding in Vermont from tropical storm Irene had a substantial geomorphological impact on many streams in the State (Springston and others, 2013). Scouring from the event at the Barton River gaging station deepened the right side of the channel by about $2.7 \mathrm{~m}$. General PSD did not appear to shift over the duration of the study, as indicated by the relatively consistent fraction of suspended sediment as finegrained particles before and after tropical storm Irene (fig. 6). The percentages of sands and fines as a function of SSC did not change significantly when tested by using analysis of covariance (Helsel and Hirsch, 2002) with a categorical marker variable to indicate whether the sample was taken before or after tropical storm Irene.

Insight on changes in PSD during storms was gained by examining SSC/SCB hysteresis during the May 21-26, 2013, storm. SSC/SCB hysteresis (fig. 5C) had a clockwise pattern similar to SSC/Q hysteresis (fig. 5B) but with a less pronounced hysteresis loop. A study in Georgia that investigated changes in the PSD over the course of several individual storms found that changes in the fine silt- to clay-sized fraction could explain observed SSC/turbidity hysteresis (Landers and Sturm, 2013). Because turbidity and backscatter are both surrogates (optical and acoustic, respectively) for SSC that are controlled by the physical properties of sediment in water, it is plausible that changes in the PSD within storms that explained the optical hysteresis (observed in Georgia) would extend to the acoustic hysteresis (observed in the Barton River). Follow up work on the Barton River would involve collecting multiple samples over several individual storms for a full analysis of PSD, including better differentiation within the fine fraction. In the absence of such data for the Barton River, the mechanism to explain SSC/ SCB hysteresis is not entirely clear, although within-storm changes in sediment source are a possibility.

\section{Relations Between Sand- and Fine-Grained Sediments to Backscatter and Attenuation}

Earlier, we had identified the question of general applicability of the theory that backscatter is mostly caused by sands and attenuation is mostly caused by fines. The strong relation between SCB and the logarithm of sand-sized (greater than $62.5 \mu \mathrm{m}$ ) suspended sediment $\left(\mathrm{r}^{2}=0.83\right.$, table 2; fig. 7) found in the Barton River also was observed in the Colorado River (Topping and others, 2007), Gunnison River (Wright and others, 2010), Snake, and Clearwater Rivers (Wood and Teasdale, 2013) and was theoretically predicted by Wright and others (2010). The slope (0.07) of the log-linear regression between the concentration of sand and SCB (red line in fig. 7) at the Barton River compares well with the slopes of the models for the Clearwater River (0.074), and the Snake, Gunnison and Colorado Rivers (0.1 each), as well as with the theoretical slope of equation 1.

A moderately strong relation between the concentrations of fine-grained suspended sediments (as logarithms) and SCB was observed at the Barton River $\left(r^{2}=0.65\right)$, in agreement with regression relations observed for data from the Clearwater $\left(r^{2}=0.78\right)$ 
and Snake $\left(r^{2}=0.81\right)$ Rivers (Wood and Teasdale, 2013) in Idaho. However, the fine-grained SSCs from the Barton River related weakly to sediment-driven acoustic attenuation $\left[\mathrm{r}^{2}=0.22\right.$ or 0.37 (logarithm) in table 2; fig. 8]. This is a similar result to findings from the Clearwater and Snake Rivers in Idaho (Wood and Teasdale, 2013) and the tidal Hudson River in New York (Wall and others, 2006), and this result contrasts with theoretical predictions and findings from the Colorado and Gunnison Rivers, where the degree of sediment-driven acoustic attenuation along the beam path was closely related to fines (Topping and others, 2007; Wright and others, 2010).

Several factors may help to explain the weak relation between sediment-driven acoustic attenuation and fines at the Barton River. The main factor most likely is the relatively low concentration of fines ( 2 to $306 \mathrm{mg} / \mathrm{L}$ ) and low sediment attenuation ( 0 to $1 \mathrm{~dB} / \mathrm{m}$ ) and narrow ranges of both parameters in samples from the Barton River. In contrast, the Gunnison River had concentrations of fines ranging from 0 to $6,000 \mathrm{mg} / \mathrm{L}$ and sediment attenuation ranging between 0 and $10 \mathrm{~dB} / \mathrm{m}$ (Wright and others, 2010). The narrower ranges in these values in the Barton River indicate a less complex and variable sediment supply regime than in the Gunnison River.

A second factor may be that attenuation is not universally important for fines; it increases in importance as particles decrease in size from about $20 \mu \mathrm{m}$ (fig. 9). As particle size increases from about 20 to $62.5 \mu \mathrm{m}$, all still within the range of fines, the relative importance of backscatter increasingly dominates over attenuation. Thus, the premise that attenuation relates to fines is more precisely stated as attenuation relates strongly to the finest of fines, or particles less than $20 \mu \mathrm{m}$. Because the fine size class for the Barton River was not subdivided, that is determined only as less than $62.5 \mu \mathrm{m}$, the better relation of fine concentration with backscatter than attenuation suggests that the fine particles from the Barton River may be predominantly between 20 and $62.5 \mu \mathrm{m}$.

A third potential factor that might be related to the weak relation between sediment-driven acoustic attenuation and fines is the presence of organic matter, which was found to increase variability between fines and sediment attenuation at the Clearwater and Snake Rivers, especially at low SSCs (Wood and Teasdale, 2013). Although organic matter was not measured at the Barton River, potential sources could be from agriculture along the Barton River or wetlands in the vicinity of and upland of the streamgage (along the town line between Coventry and Irasburg; fig. 1).

\section{Selection of Regression Model}

The SAID program was used to test various simple and multiple linear regression models. The best fit regression models had (1) variables that were all significant, (2) residual and normal probability plots that verified that assumptions required for regression were met, (3) a high coefficient of determination $\left(\mathrm{r}^{2}\right)$, (4) low root mean squared error (RMSE), and (5) no or few outliers. Independent or predictor variables included in regression models were MB, WCB, and SCB; discharge; the fluidabsorption and sediment-driven acoustic attenuation coefficients; and a marker variable for SSC/Q hysteresis to indicate the position of the sample in the flow regime. The marker variable assigned to each sample consisted of a binary value of 0 or 1 ; 0 for samples collected during rising stages of the hydrograph and 1 for samples during falling or stable stages. Regression model results for estimating SSC and phosphorus are summarized in appendixes 3 and 4.

$\mathrm{SSC} / \mathrm{Q}$ hysteresis was included as a potential predictor variable in the regression models because SSC/Q and SSC/ SCB hysteresis was observed in the Barton River (fig. 5A-C). In addition, prominent differences in sediment-driven acoustic attenuation were observed between samples taken during rising stage and those taken during falling or stable stages (fig. 8). Figure 8 suggests that accounting for SSC/Q hysteresis, as a surrogate for SSC/SCB hysteresis, may improve the acoustic-based prediction of SSC. The best fit lines and respective $r^{2}$ values for the rising stage and falling or stable stage samples shown in figure 8 do not include the two outliers, both near peak discharge of extremely large events, indicated as circled points on the plot. Although it is unclear from the $\mathrm{r}^{2}$ values ( 0.16 for samples during rising stage and 0.01 for samples during falling or stable stages) whether separating points into two populations improves relations compared with the unseparated sample set $\left(r^{2}=0.10\right.$, not shown), there is a distinct visual contrast between the regression lines in figure 8. In particular, the relation between fines and sediment-driven acoustic attenuation appears to be improved for rising-stage samples compared with falling or stablestage samples and also compared with the total population. Therefore, even if the binary hysteresis term does not significantly improve the overall regression model, this result suggests a potential improvement to models that might focus on concentrations during rising stages only.

Linear regression models for predicting SSC (table 3) show that backscatter (regressions 5, 9 and 13) is a better predictor variable than discharge (regression number 1). Including SSC/Q hysteresis as a predictor variable improved the discharge model (compare 2 and 1) but had no effect on the backscatter model (compare regressions 7 and 5, 11 and 9, or 15 and 13). Discharge (expressed either as observed or as the logarithm, whichever yielded the better result) included with backscatter was insignificant (regression 6,10, and 14). The fluid-absorption and sediment-driven acoustic attenuation coefficients were significant predictors on their own for SSC (regressions 3 and 4), though with low power and high error, but became insignificant covariates when combined with backscatter terms in models to predict SSC. 
Regression models based on MB, WCB, and sediment-corrected backscatter (SCB) preformed equally well as predictors of SSC (table 3). The similar ability to predict SSC among backscatter terms may be attributed partially to the low values and narrow range in the sediment-driven acoustic attenuation $(0$ to $1 \mathrm{~dB} / \mathrm{m})$ at the Barton River. The regression, based on SCB (model 13), was selected for estimating SSC because SCB potentially removes bias from the raw backscatter. Instrument, fluid, and sediment corrections applied to SCB remove potential bias of attenuation caused by changes across the lateral profile, potential seasonal effects by correcting for temperature, and implicit dependencies from regressions for properties associated with the local instrument configuration and settings.

The regression model based on SCB had five observations flagged by SAID as having high influence (appendix 3). Four of these observations were for samples with SSCs below $10 \mathrm{mg} / \mathrm{L}$, which may be the lower limit of the sensitivity of backscatter to SSC (Gray and Gartner, 2009). All observations were kept in the regression models because the four samples less than $10 \mathrm{mg} / \mathrm{L}$ were the best data available to estimate low concentrations, and there was no justification to delete the fifth observation, because it was only slightly above the DFFITS test statistic (the change in the predicted value for a point when that point is omitted from the regression) that indicates high influence (appendix 3).

The regression equation based on discharge and SSC/Q hysteresis (number 18, table 3) was selected for use in the estimation of phosphorus concentrations. The phosphorus regressions differed from the SSC regressions in that the regression based on the logarithm of discharge and hysteresis (number 18) had the highest $r^{2}$ (by at least 0.07 ) and the lowest RMSE (by at least 0.03 ) of all the regression equations evaluated for estimating phosphorus, including those based on backscatter. These better regression metrics support the selection of discharge over backscatter. As with SSC, phosphorus regression metrics based on MB, WCB, and SCB were all nearly identical (table 3).

Adding SSC/Q hysteresis to backscatter in the regression equations for phosphorus boosted the $\mathrm{r}^{2}$ value by 0.10 to 0.12 (compare regression 21 to 23, 25 to 27, and 29 to 31), compared with an increase of 0.01 to 0.04 to the $\mathrm{r}^{2}$ value for SSC when $\mathrm{SSC} / \mathrm{Q}$ hysteresis was included as a factor. These results suggest SSC/Q hysteresis was more effective in predicting phosphorus concentrations than in predicting SSC. Landers and Sturm (2013) showed that small changes in the distribution of fine-grained sediments can have a significant impact on SSC/turbidity hysteresis. If phosphorus is preferentially sorbed to fines, which are particularly sensitive to SSC/turbidity hysteresis, then one might expect that the use of SSC/Q hysteresis, as a surrogate for SSC/turbidity hysteresis, could also be an important predictor variable for phosphorus.

Regression models were less accurate at predicting values of phosphorus concentration based on backscatter than at predicting SSC. For example, in table 3 the $\mathrm{r}^{2}$ of the simple linear regressions for phosphorus based on backscatter (regressions 21, 25, and 29) was lower than that for the regressions of SSC based on backscatter (regressions 5, 9, and 13). It is expected that estimates of phosphorus concentrations based on backscatter would be less accurate than estimates for SSCs because backscatter is a measure of the strength of sound returned (bouncing off particles) to the instrument, which directly relates to SSC. We are attempting to estimate phosphorus concentrations by extrapolating from a theory of the relation between SSC and backscatter; this scheme is only as accurate as the strength of the relation between phosphorus and SSC in the Barton River. Despite the strong relation between phosphorus concentration and SSC for samples from the Barton River, about 17 percent of the variability in the phosphorus concentrations remains unexplained by SSC (fig. 4).

Three outliers were identified by the DFFITS statistic for the regression to predict the logarithm of phosphorus based on discharge and SSC/Q hysteresis (appendix 4). Two of the three outliers were samples from the extreme events identified in figure 8. The third outlier was observed on May 2, 2013, when the measured phosphorus in the sample was $197 \mu \mathrm{g} / \mathrm{L}$ and discharge was close to base flow at $209 \mathrm{ft}^{3} / \mathrm{s}$. Because the DFFITS statistics for the first two outliers were marginally outside the range of the test criteria, they were not omitted as was the case with SSC. The DFFITS statistic for the third observation was about double the test criterion (0.467), although for lack of a good reason it also was not omitted.

\section{Estimation of Constituent Concentrations}

The relation between constituent concentrations and surrogates, regression numbers 13 and 18 from table 3, were used to estimate continuous SSC and phosphorus concentration. A discussion of each constituent follows.

\section{Suspended Sediment}

Observed SSCs ranged from 2 to $413 \mathrm{mg} / \mathrm{L}$ and estimated SSCs ranged from 4 to $489 \mathrm{mg} / \mathrm{L}$ (appendix 3). Agreement between estimated and measured SSC ranges from similar to about an order-of-magnitude difference, with many estimates fairly close to the 1:1 reference line (fig. 10). Estimated continuous data for the final 45 days of record (fig. 11) demonstrated the generally close agreement between estimated and measured SSC; all estimates, except for two at low concentrations, were within the 90-percent confidence intervals. Pronounced diurnal fluctuations in SCB (and in estimated SSC, which is based on $\mathrm{SCB}$ ), noted in the time-series plots (fig. 11) also are seen in the temperature and battery voltage records at the site but not in 
velocity or discharge, which suggests a power issue (that is, that the battery voltage is changing diurnally). The battery voltage record indicates a power issue. Because the average SNR fluctuated by less than $2 \mathrm{~dB}$, the record was not corrected.

Samples with concentrations less than about $40 \mathrm{mg} / \mathrm{L}$ were consistently overestimated (fig. 10), including two mid-May points with measured concentrations of 4 and $5 \mathrm{mg} / \mathrm{L}$ and estimated concentrations of approximately $20 \mathrm{mg} / \mathrm{L}$ (fig. 11). While weak model performance at low SSC is consistent with acoustic method specifications of a minimum SSC of approximately $10 \mathrm{mg} / \mathrm{L}$ for optimal performance (Topping and others, 2007), low SSC generally is neither an environmental nor an engineering concern. Over 99 percent of the total flux of suspended sediment during the study period was transported when concentrations were above $10 \mathrm{mg} / \mathrm{L}$ (and 93 percent of the flux when SSCs were above $50 \mathrm{mg} / \mathrm{L}$ ).

\section{Phosphorus}

For phosphorus, observed concentrations ranged from 12 to $292 \mu \mathrm{g} / \mathrm{L}$ and estimated concentrations ranged from 17 to $287 \mu \mathrm{g} / \mathrm{L}$ (appendix 4). Estimated concentrations of phosphorus also are fairly close to measured values (fig. 12). Low concentrations of phosphorus tend to be overestimated and high concentrations have no uniform tendency. The estimated continuous record of phosphorus concentrations for the final 45 days of the study period (fig. 13) shows an irregular toothed curvature pattern that represents an artifact of the binary hysteresis term coupled with discharge. Most of the measured phosphorus concentration values are within the 90-percent confidence intervals. The best predictions for phosphorus were for mid-range concentrations less than $100 \mu \mathrm{g} / \mathrm{L}$. The unexplained outlier referred to earlier in the DFFITS discussion is evident in figures 12 and 13. As expected and previously discussed (where low concentrations extend beyond the method specifications; Topping and others, 2007), the two low-concentration sampled points in the middle of May that were overestimated for suspended sediment also were overestimated for phosphorus.

\section{Summary and Conclusions}

The U.S. Geological Survey, in cooperation with the Vermont Department of Environmental Conservation, collected water samples from the Barton River near Coventry, Vermont, from 2010 to 2013 to estimate continuous concentration curves of suspended sediment and phosphorus using streamflow and acoustic backscatter. Acoustic backscatter is an ancillary measurement at the Barton River streamgage generated from the acoustic Doppler profiler (ADP) that was installed at the site because the stage-discharge rating was occasionally confounded by backwater from Lake Memphremagog. Whereas the use of acoustic backscatter as a surrogate for estimating suspended-sediment concentration (SSC) has been broadly investigated, this study tested its applicability to estimating total phosphorus. Another topic addressed by this study is whether recent refinements to equations used to estimate SSC for different classes of particle size, developed for conditions in the Colorado River, are applicable to a Vermont stream.

Long-term and within-storm changes in Barton River particle-size distribution (PSD) were examined to help interpret results from using acoustic surrogates for estimating SSC. The PSD in the Barton River was found unchanged between periods before and after tropical storm Irene. Some degree of within-storm changes in the PSD were inferred from the existence of hysteresis between SSC and sediment-corrected backscatter (SCB).

Data from the Barton River did not fully support the hypothesis that backscatter is mostly caused by sands and attenuation is mostly caused by fines. Sands, fines, and total suspended-sediment concentrations in the Barton River all related better to backscatter than to sediment-driven acoustic attenuation. This finding is consistent with findings for the Clearwater and Snake Rivers in Idaho but different from findings for the Gunnison River in Colorado, where fines related strongly to attenuation. The low values and narrow range of SSCs and sediment-driven acoustic attenuations observed at Barton, Clearwater and Snake Rivers compared to the Gunnison River might help to explain this difference among rivers. Another potential factor is that the fine suspended sediment in the Barton River might be dominated by particle sizes between 20 and $62.5 \mu \mathrm{m}$, which theoretically have a stronger association with backscatter than sediment-driven acoustic attenuation. Targeted sampling during different flow conditions, coupled with a full analysis of the PSD within the fine size category (less than $62.5 \mu \mathrm{m}$ ), could help define the role of sediment-driven acoustic attenuation at this site.

The best regression equations for estimating SSC used backscatter as the predictor rather than discharge. Acoustic backscatter is a better predictor of SSC than discharge most likely because the measurement of acoustic backscatter has a direct relation to SSC, whereas discharge does not. Backscatter may also be a better predictor of SSC than discharge because hysteresis between SSC and backscatter was less than hysteresis between SSC and discharge. All three backscatter terms(1) measured (MB), (2) water-corrected (WCB), and (3) sediment-corrected (SCB) - performed equally well as predictors of SSCs and phosphorus concentrations at the Barton River site. The similar abilities to predict SSC among backscatter terms may partially be attributed to the low values and narrow range in the sediment-driven acoustic attenuation ( 0 to 1 decibel per 
meter) at the Barton River. The regression based on SCB was selected for estimating SSC because it removes potential bias as the result of attenuation and temperature fluctuations. The regression model chosen to estimate phosphorus, based on the best regression metrics, included terms for the logarithm of discharge and discharge hysteresis. The finding that discharge hysteresis was a significant predictor of phosphorus concentrations might be related to preferential sorption of phosphorus to fine-grained sediments, which were found in a Georgia study to be particularly sensitive to hysteresis (between SSC and turbidity). Sedimentdriven acoustic attenuation alone produced a significant regression model for SSC and phosphorus, but with low power and high error, and was not significant when used as a covariate with backscatter.

\section{References Cited}

Christensen, V.G., Jian, Xiaodong, and Ziegler, A.C., 2000, Regression analysis and real-time water-quality monitoring to estimate constituent concentrations, loads, and yields in the Little Arkansas River, south-central Kansas, 1995-99: U.S. Geological Survey Water-Resources Investigations Report 00-4126, 36 p.

Duan, Naihua, 1983, Smearing estimate-A nonparametric retransformation method: Journal of the American Statistical Association, v. 78, p. 605-610.

Edwards, T.E., and Glysson, G.D., 1999, Field methods for measurement of fluvial sediment: U.S. Geological Survey Techniques of Water-Resources Investigations, book 3, chap. C2, 89 p. [Also available at http://water.usgs.gov/osw/ techniques/sedimentpubs.html.]

Flammer, G.H., 1962, Ultrasonic measurement of suspended sediment: U.S. Geological Survey Bulletin 1141-A, 48 p.

Gartner, J.W., 2004, Estimating suspended solids concentrations from backscatter intensity measured by acoustic Doppler current profiler in San Francisco Bay, California: Marine Geology, v. 211, p. 169-187.

Gray, J.R., and Gartner, J.W., 2009, Technological advances in suspended-sediment surrogate monitoring: Water Resources Research, v. 45, no. 7, paper W00D29, 20 p., http://dx.doi.org/10.1029/2008WR007063.

Gray, J.R., and Landers, M.N., 2014, Measuring suspended sediment, in Ahuja Satinder, ed., Comprehensive water quality and purification: Amsterdam, Elsevier, v. 1, p. 157-204, accessed July 31, 2014, at http://water.usgs.gov/osw/techniques/sediment/ gray_landers_elsevier_chapter_12_10_17_2013.pdf.

Grayson, R.B., Finlayson, B.L., Gippel, C.J., and Hart, B.T., 1996, The potential of field turbidity measurements for the computation of total phosphorus and suspended solids loads: Journal of Environmental Management, v. 47, p. 257-267.

Helsel, D.R., and Hirsch, R.M., 2002, Statistical methods in water resources: U.S. Geological Survey Techniques of WaterResources Investigations, book 4, chap. A3, 522 p., http://pubs.usgs.gov/twri/twri4a3/.

Hirsch, R.M., 2012, Flux of nitrogen, phosphorus, and suspended sediment from the Susquehanna River Basin to the Chesapeake Bay during tropical storm Lee, September 2011, as an indicator of the effects of reservoir sedimentation on water quality: U.S. Geological Survey Scientific Investigations Report 2012-5185, 17 p. [Also available at http://pubs.usgs.gov/ $\operatorname{sir} / 2012 / 5185 /$.

Hodgkins, G.A., and Dudley, R.W., 2011, Historical summer base flow and stormflow trends for New England rivers: Water Resources Research, v. 47, no. 7, paper W07528, 16 p., http://dx.doi.org/10.1029/2010WR009109.

Homer, Collin, Dewitz, Jon, Fry, Joyce, Coan, Michael, Hossain, Nazmul, Larson, Charles, Herold, Nate, McKerrow, Alexa, VanDriel, J.N., and Wickham, James, 2007, Completion of the 2001 National Land Cover Database for the conterminous United States: Photogrammetric Engineering and Remote Sensing, v. 73, no. 4, p. 337-341.

Landers, M.N., 2010, Review of methods to estimate fluvial suspended sediment characteristics from acoustic surrogate metrics: Joint Federal Interagency Conference, 2d, Las Vegas, Nev., June 27-July 1, 2010, 12 p., accessed July 24, 2013, at http://acwi.gov/sos/pubs/2ndJFIC/Contents/2C_Landers_030910_paper.pdf.

Landers, M.N., Arrigo, Jennifer, and Gray, J.R., 2012, Advancing hydroacoustic technologies for sedimentology research and monitoring: Eos Transactions American Geophysical Union, v. 93, chap. 26, 244 p., http://dx.doi.org/10.1029/2012EO260007. 
Landers, M.N., and Sturm, T.W., 2013, Hysteresis in suspended sediment to turbidity relations due to changing particle size distributions: Water Resources Research, v. 49, no. 9, p. 5487-5500, http://dx.doi.org/10.1002/wrcr.20394.

Levesque, V.A., and Oberg, K.A., 2012, Computing discharge using the index velocity method: U.S. Geological Survey Techniques and Methods, book 3, chap. A23, 148 p.

Mueller, D.K., and Spahr, N.E., 2006, Nutrients in streams and rivers across the Nation-1992-2001: U.S. Geological Survey Scientific Investigations Report 2006-5107, 44 p.

Mueller, D.S., Wagner, C.R., Rehmel, M.S., Oberg, K.A., and Rainville, Francois, 2013, Measuring discharge with acoustic Doppler current profilers from a moving boat (ver. 2.0, December 2013): U.S. Geological Survey Techniques and Methods, book 3, chap. A22, 95 p., http://dx.doi.org/10.3133/tm3A22.

Needham, Dan, and Russo, Christina, 2013, Department of Environmental Conservation Laboratory quality assurance plan: Vermont Department of Environmental Conservation Web page, accessed August 16, 2013, at http://www.anr.state.vt.us/dec/ lab/htm/QualityControl.htm.

Rasmussen, P.P., Gray, J.R., Glysson, G.D., and Ziegler, A.C., 2009, Guidelines and procedures for computing time-series suspended-sediment concentrations and loads from in-stream turbidity-sensor and streamflow data: U.S. Geological Survey Techniques and Methods, book 3, chap. C4, 52 p.

Shreve, E.A., and Downs, A.C., 2005, Quality-assurance plan for the analysis of fluvial sediment by the U.S. Geological Survey Kentucky Water Science Center Sediment Laboratory: U.S. Geological Survey Open-File Report 2005-1230, 28 p.

Springston, G.E., Underwood, K.L., Robinson, Keith, and Swanberg, Ned, 2013, Rainfall, flood magnitude, and geomorphic impacts of tropical storm Irene in Vermont, with a focus on the White River Watershed, east-central Vermont: Vermont Experimental Program to Stimulate Competitive Research, Research on Adaptation to Climate Change Seminar Series, accessed September 24, 2013, at http://www.uvm.edu/ epscor/pdfFiles/IreneWhiteRiver_UVM_RACC_06132013.pdf.

Thompson, E.H., and Sorenson, E.R., 2000, Wetland, woodland, and wildland-A guide to the natural communities of Vermont: The Nature Conservancy and the Vermont Department of Fish and Wildlife, 456 p., accessed August 16, 2013, at $h t t p: / / w w w$. vtfishandwildlife.com/books/Wetland, Woodland, Wildland/.

Thorne, P.D., and Hanes, D.M., 2002, A review of acoustic measurements of small-scale sediment processes: Continental Shelf Research, v. 22, p. 603-632.

Topping, D.J., Wright, S.A., Melis, T.S., and Rubin, D.M., 2007, High-resolution measurements of suspended-sediment concentration and grain size in the Colorado River in Grand Canyon using a multi-frequency acoustic system: International Symposium on River Sedimentation, 10th, Moscow, August 1-4, 2007, Proceedings, p. 330-339.

Urick, R.J., 1975, Principles of underwater sound (2d ed.): New York, McGraw Hill, 384 p.

U.S. Environmental Protection Agency, 2013, Approved TMDLs region 1-New England: U.S. Environmental Protection Agency Web page, accessed March 14, 2014, at http://www.epa.gov/region1/eco/tmdl/approved.html\#vt.

U.S. Geological Survey, 2006, Collection of water samples (ver. 2.0): U.S. Geological Survey Techniques of Water-Resources Investigations, book 9, chap. A4, accessed August 16, 2013, at http://pubs.water.usgs.gov/twri9A4/.

U.S. Geological Survey, 2011, High flows in New Hampshire and Vermont from tropical storm Irene estimated: U.S. Geological Survey, Water Resources of New Hampshire and Vermont Web page, accessed November 13, 2012, at http://nh.water.usgs. gov/WhatsNew/Irene_aug2011.htm.

University of Vermont Spatial Analysis Lab, 2005, Land cover/land use dataset for Vermont: Vermont Center for Geographic Information Web page, accessed August 3, 2006, at http://www.vcgi.org/dataware/default.cfm?layer=LCLU2002.

Vermont Agency of Natural Resources, 2006, Basin 17-Lake Memphremagog watershed assessment report: Vermont Agency of Natural Resources, Department of Environmental Conservation, Water Quality Division, 42 p., accessed August 16, 2013,

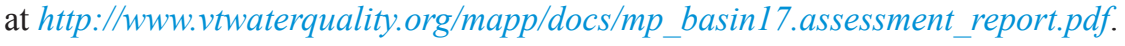

Vermont Department of Environmental Conservation, 2012, State of Vermont 2012 303(d) list of waters—Part A—Impaired surface waters in need of TMDL: Vermont Department of Environmental Conservation, Watershed Management Division, 7 p., accessed August 16, 2013, at http://www.vtwaterquality.org/mapp/docs/mp_2012_303d_Final.pdf. 
Vermont Department of Environmental Conservation, 2013, Vermont surface water management strategy—Chapter 1-Strategic framework for statewide efforts to guide surface water management: Vermont Department of Environmental Conservation Watershed Management Division Web page, accessed August 16, 2013, at http://www.watershedmanagement.vt.gov/wqd_ mgtplan/swms_ch1.htm\#_Toc277168248.

Wall, G.R., Nystrom, E.A., and Litten, Simon, 2006, Use of an ADCP to compute suspended-sediment discharge in the tidal Hudson River, New York: U.S. Geological Survey Scientific Investigations Report 2006-5055, 16 p., http://pubs.usgs.gov/ sir/2006/5055/.

Winchell, Michael, Meals, Don, Folle, Solomon, Moore, Julie, Braun, Dave, DeLeo, Christine, Budreski, Katie, and Schiff, Roy, 2011, Identification of critical source areas of phosphorus within the Vermont sector of the Missisquoi Bay basin: Lake Champlain Basin Program Technical Report 63B, 242 p., http://www.lcbp.org/techreportPDF/63B_Missisquoi_CSA.pdf.

Wood, M.S., 2014, Estimating suspended sediment in rivers using acoustic Doppler meters: U.S. Geological Survey Fact Sheet 2014-3038, 4 p., http://dx.doi.org/10.3133/fs20143038.

Wood, M.S., and Teasdale, G.N., 2013, Use of surrogate technologies to estimate suspended sediment in the Clearwater River, Idaho, and Snake River: Washington, 2008-10: U.S. Geological Survey Scientific Investigations Report 2013-5052, 30 p.

Wright, S.A., Topping, D.J., and Williams, C.A., 2010, Discriminating silt-and-clay from suspended-sand in rivers using side-looking acoustic profilers: Joint Federal Interagency Conference, 2d, Las Vegas, Nev., June 27-July 1, 2010, 12 p., http://acwi.gov/sos/pubs/2ndJFIC/Contents/2C_Wright_03_01_10_paper.pdf. 

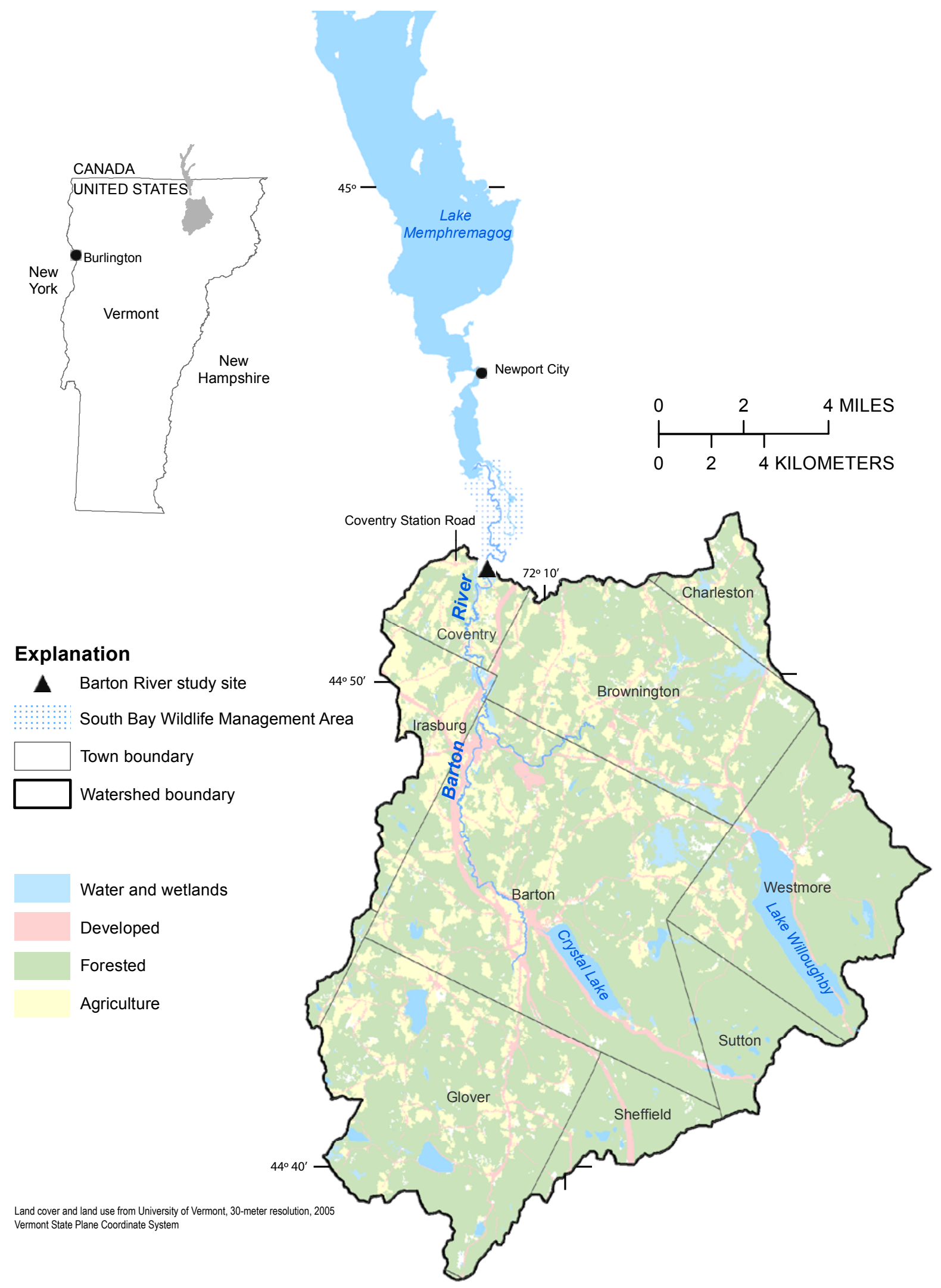

Figure 1. The location of the Barton River study site near Coventry, Vermont, and land use in the watershed 


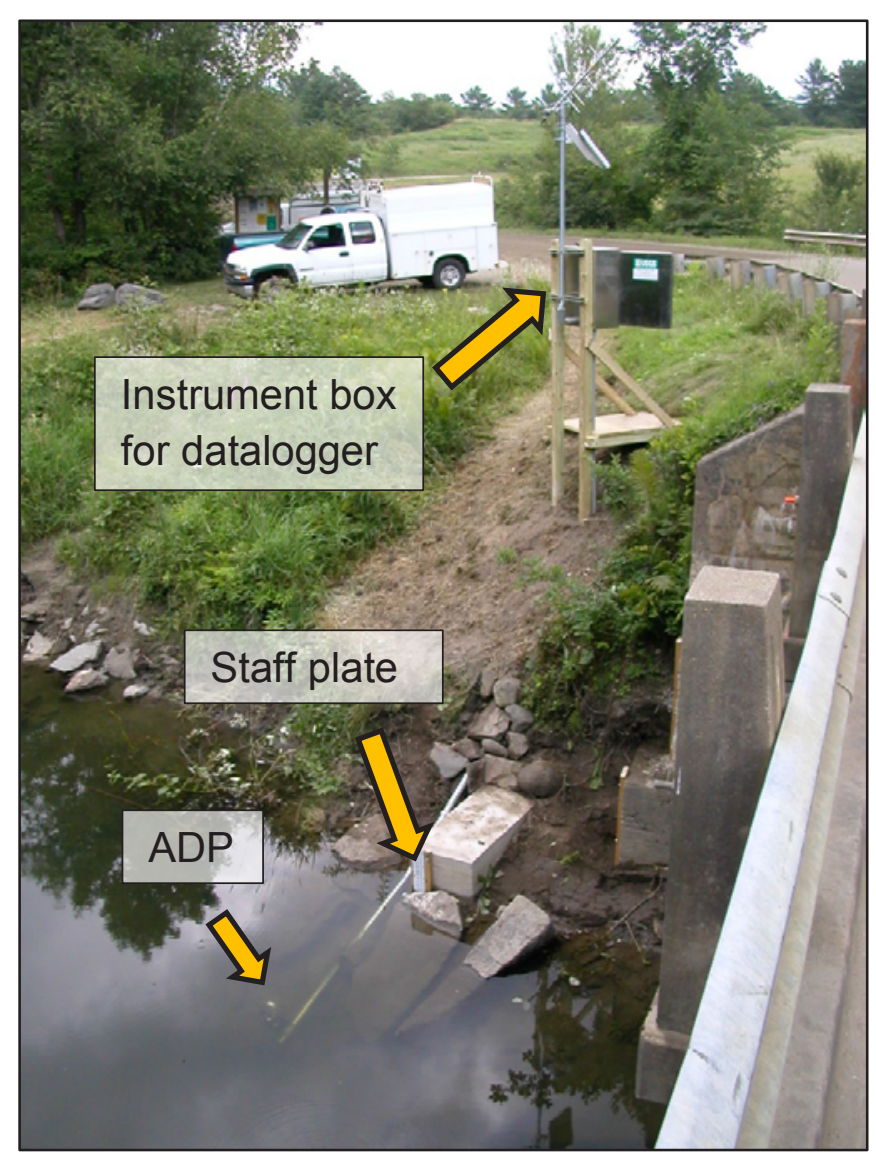

Figure 2. The acoustic Doppler profiler and staff plate mounted on the right bank of the Barton River in Coventry, Vermont. 


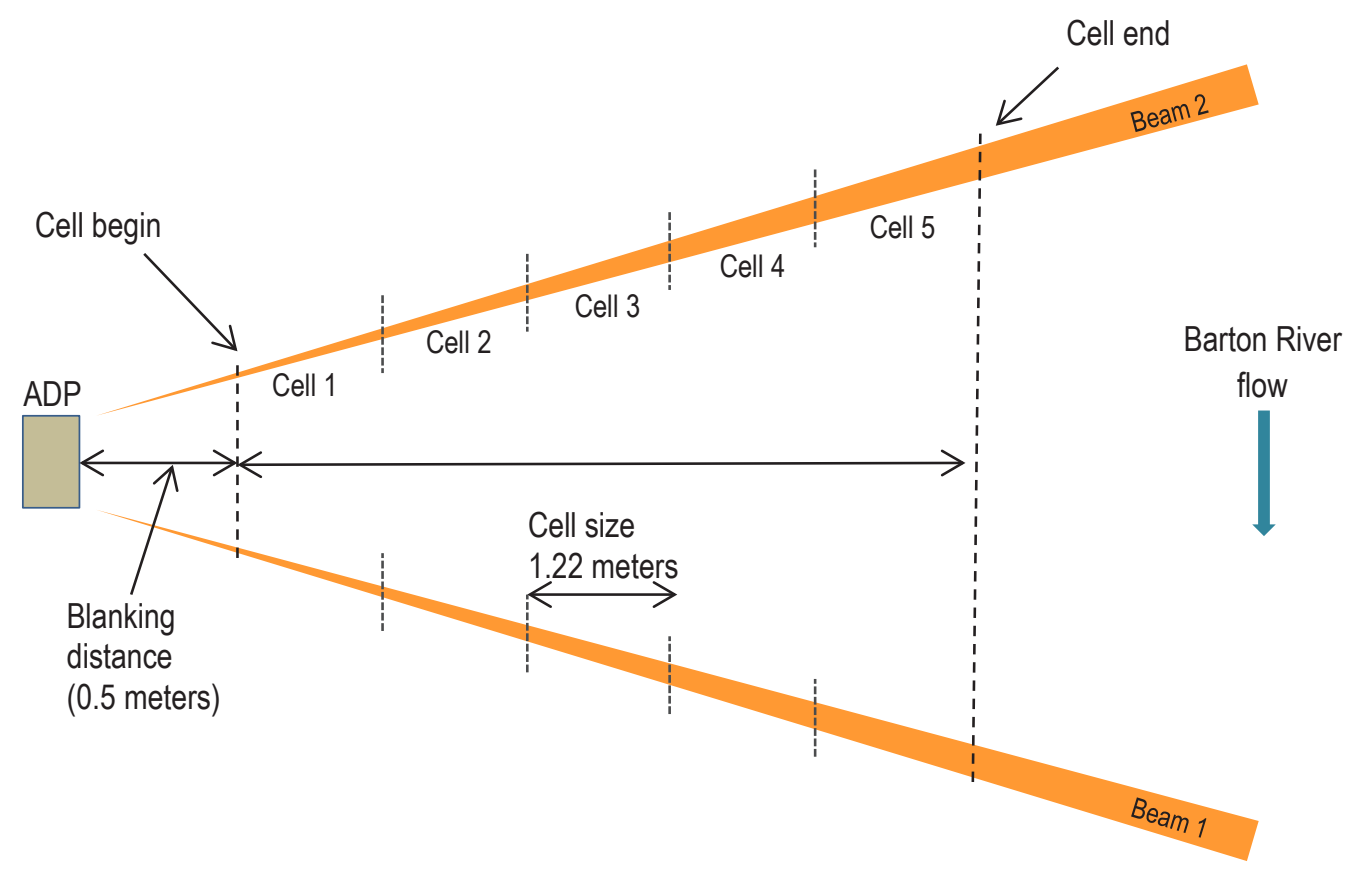

Figure 3. The acoustic Doppler profiler (ADP) used at the Barton River near Coventry, Vermont. 


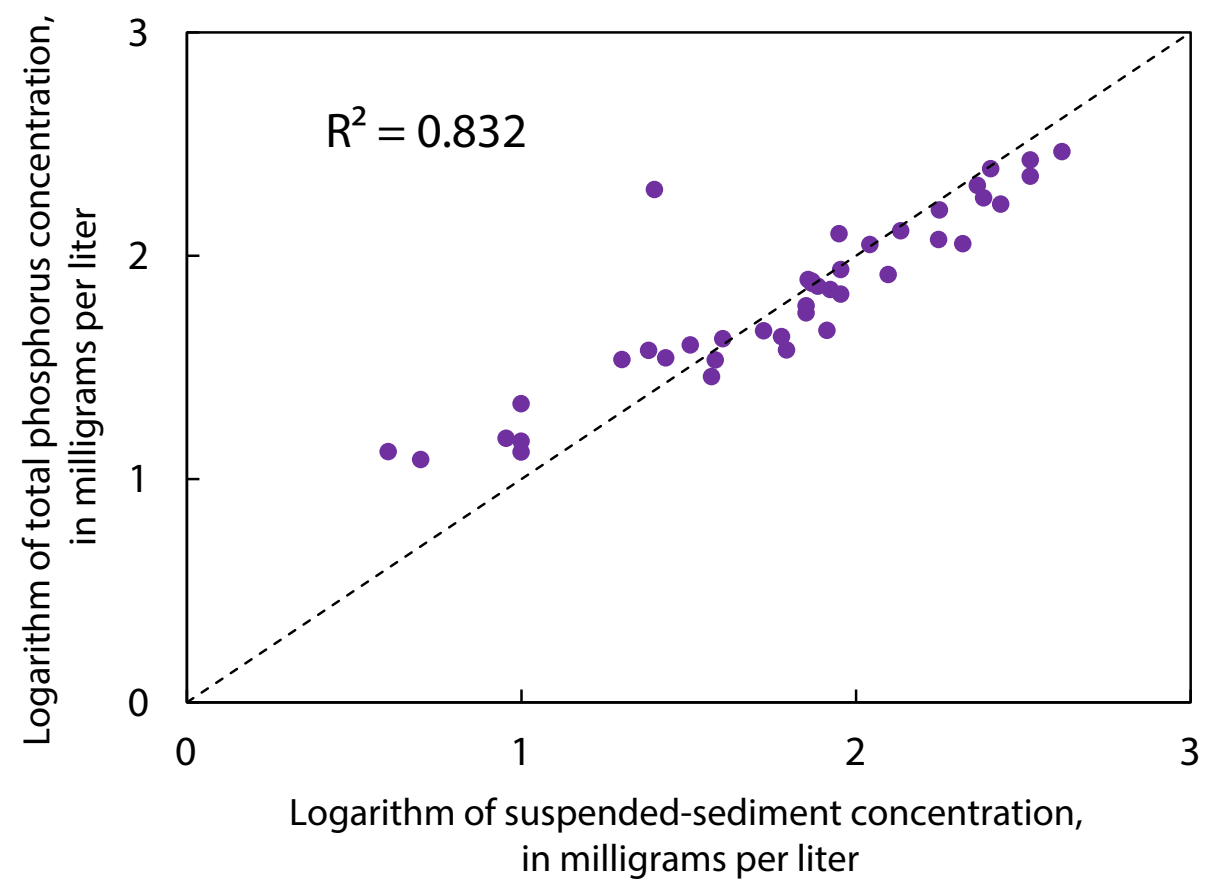

Figure 4. Concentrations of phosphorus as a function of concentrations of suspended sediment for water samples from the Barton River near Coventry, Vermont, 2010 through 2013. 


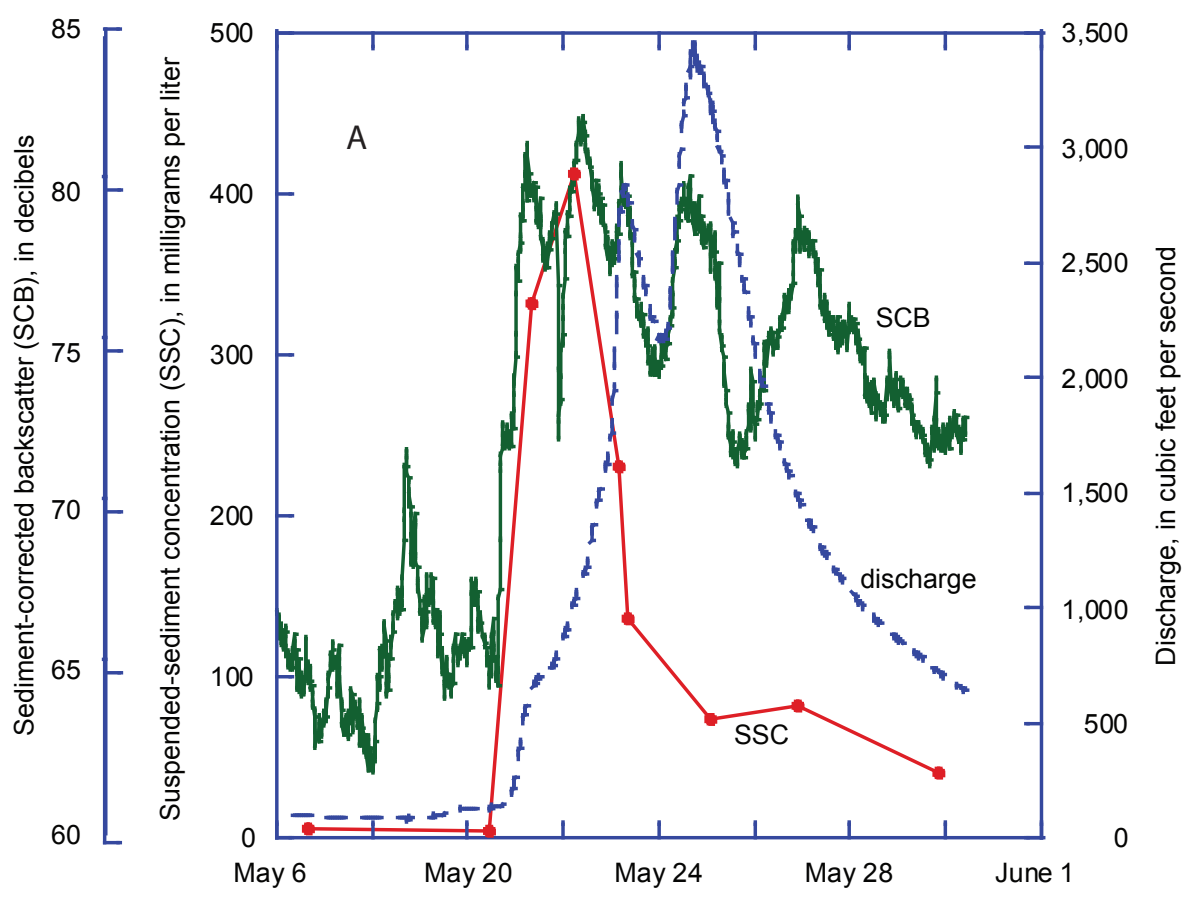

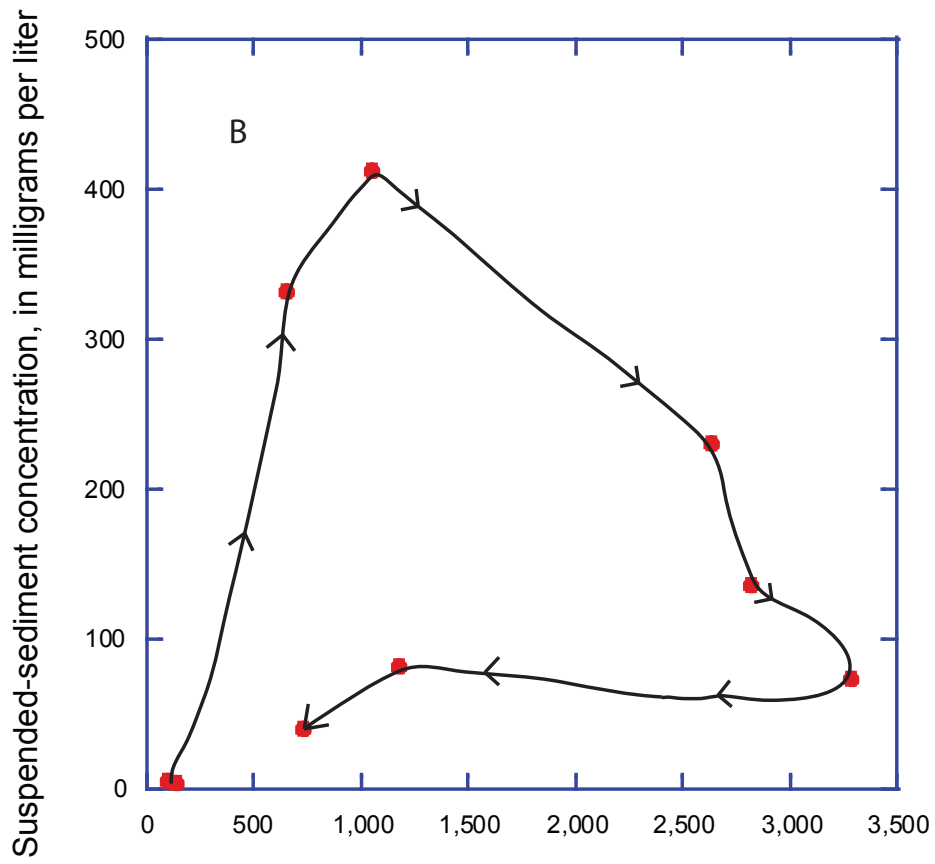

Discharge, in cubic feet per second

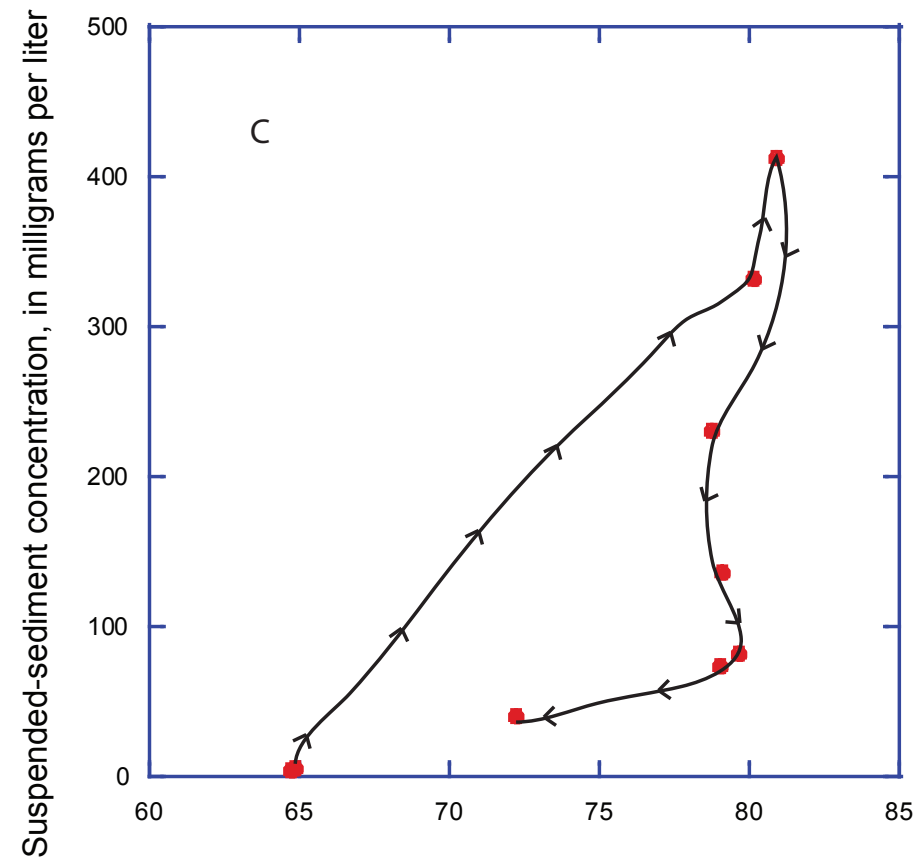

Sediment-corrected backscatter, in decibels

Figure 5. Hysteresis in suspended-sediment concentration (SSC) as a function of discharge and sediment-corrected backscatter (SCB) for a May 2013 storm at the Barton River near Coventry, Vermont, shown as A, time-series plot of SCB, SSC, and discharge; $B$, SSC/discharge hysteresis; and C, SSC/SCB hysteresis. 


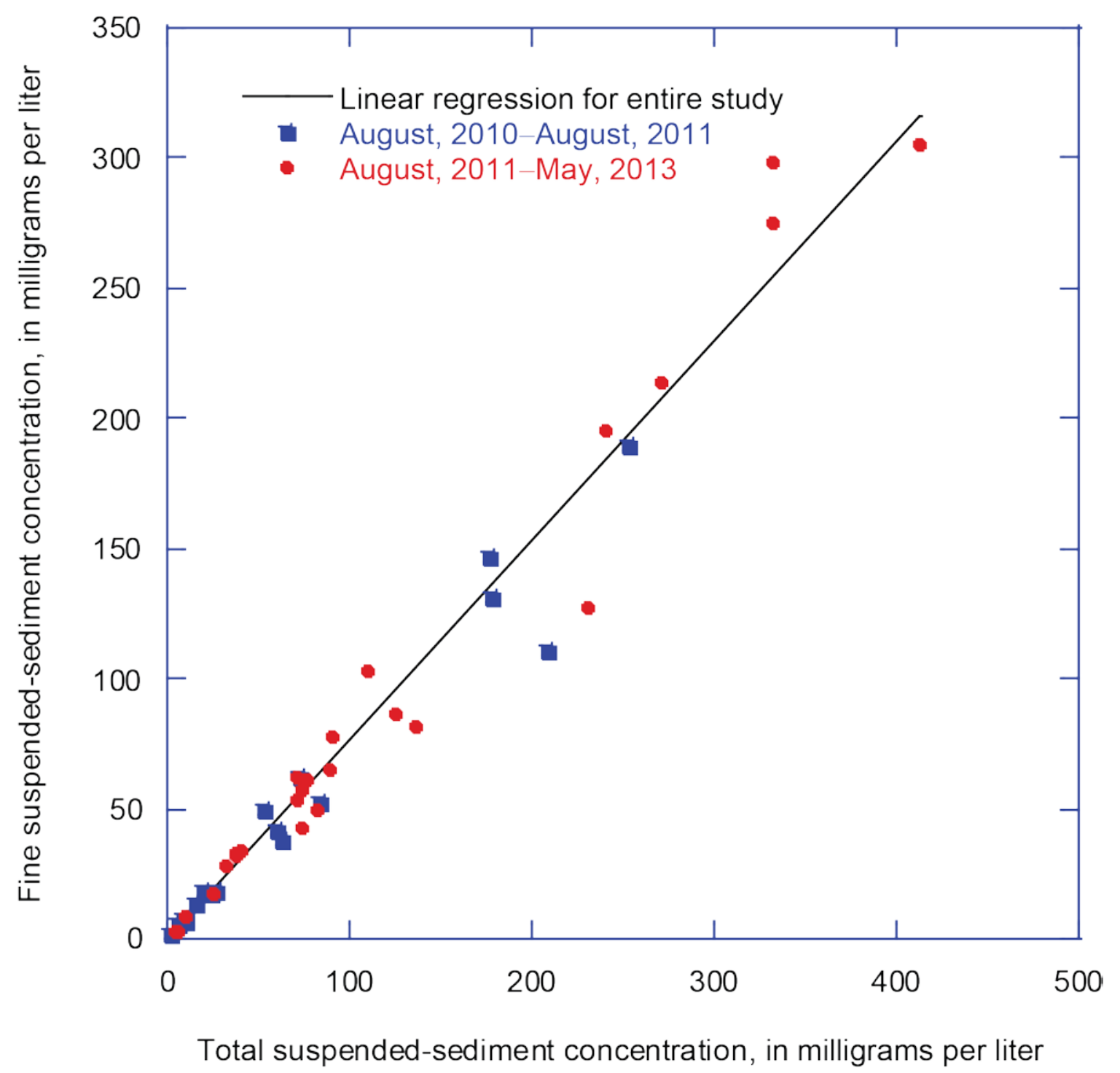

Figure 6. Concentrations of fine as a function of total suspended sediment for samples collected before and after tropical storm Irene (August 28-29, 2011), from the Barton River near Coventry, Vermont. 


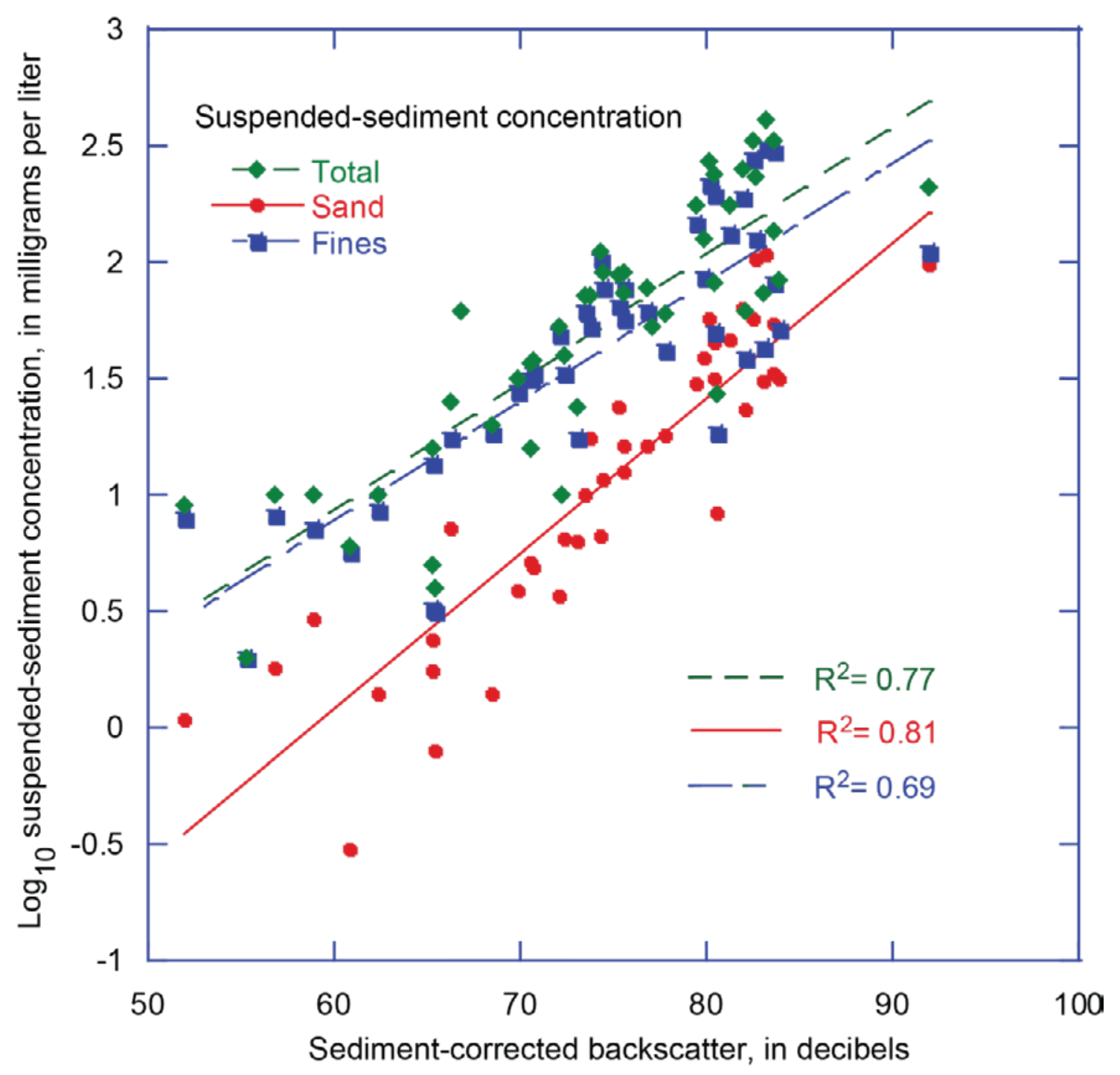

Figure 7. Best fit regression lines of suspended sediment as a function of sediment-corrected backscatter for the Barton River near Coventry, Vermont. 


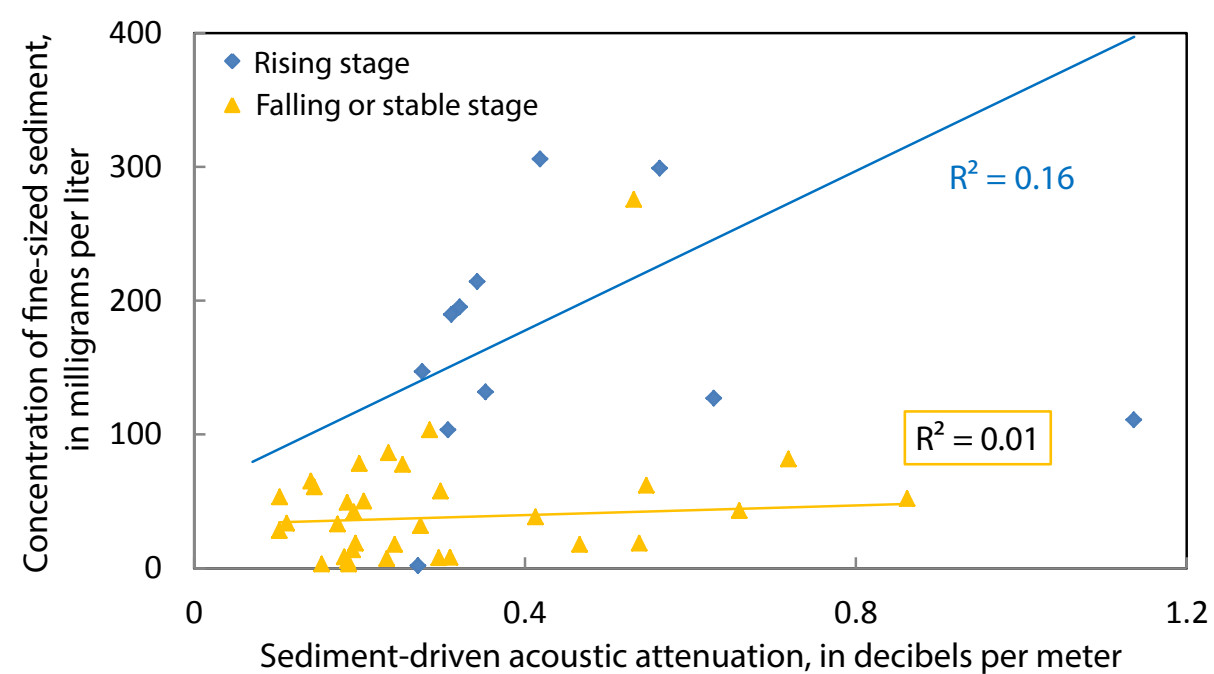

Figure 8. Concentrations of fine-grained sediment as a function of sediment-driven acoustic attenuation for samples collected during rising and falling or stable stages of the hydrograph at the Barton River near Coventry, Vermont, from 2010 through 2013. 


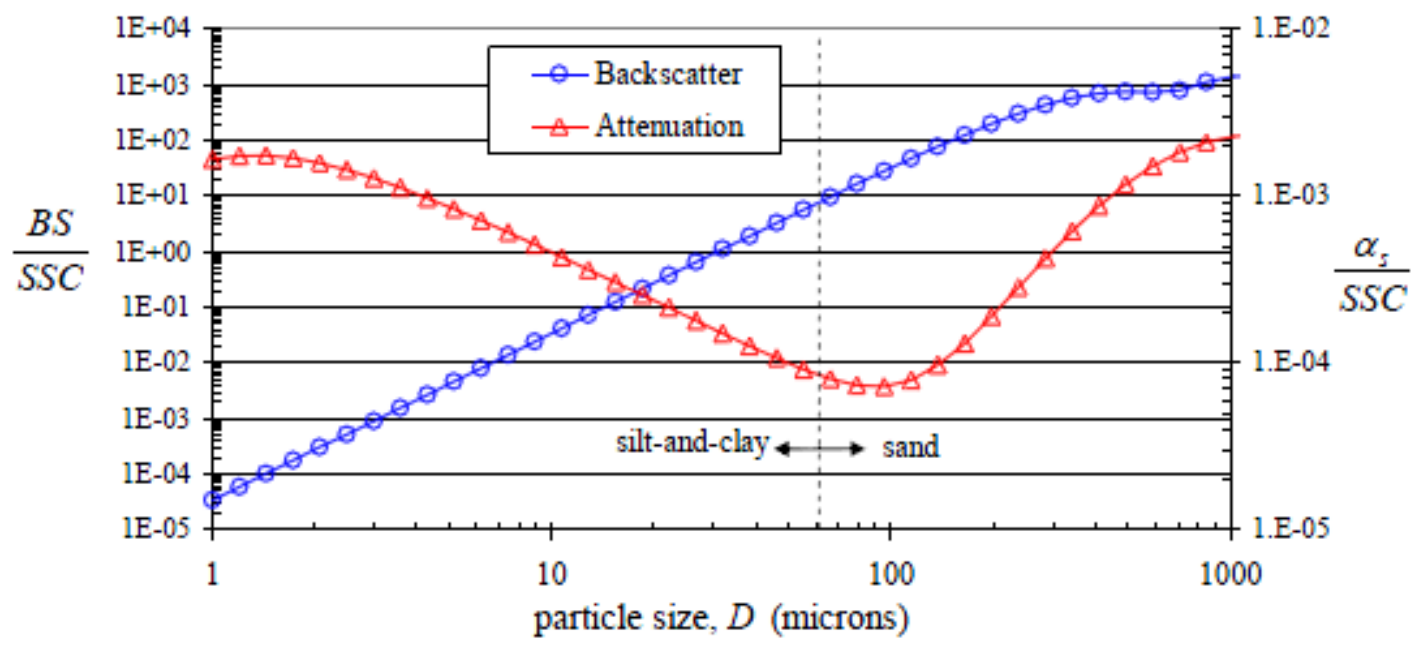

Figure 9. Theoretical relations for backscatter (left axis, blue) and attenuation (right axis, red) for a given suspended-sediment concentration as a function of particle size (at 1-megahertz frequency). 1.E- $0 n, 1 \times 10^{-n}$; micron, micrometer. From Wright and others (2010, fig. 3). 


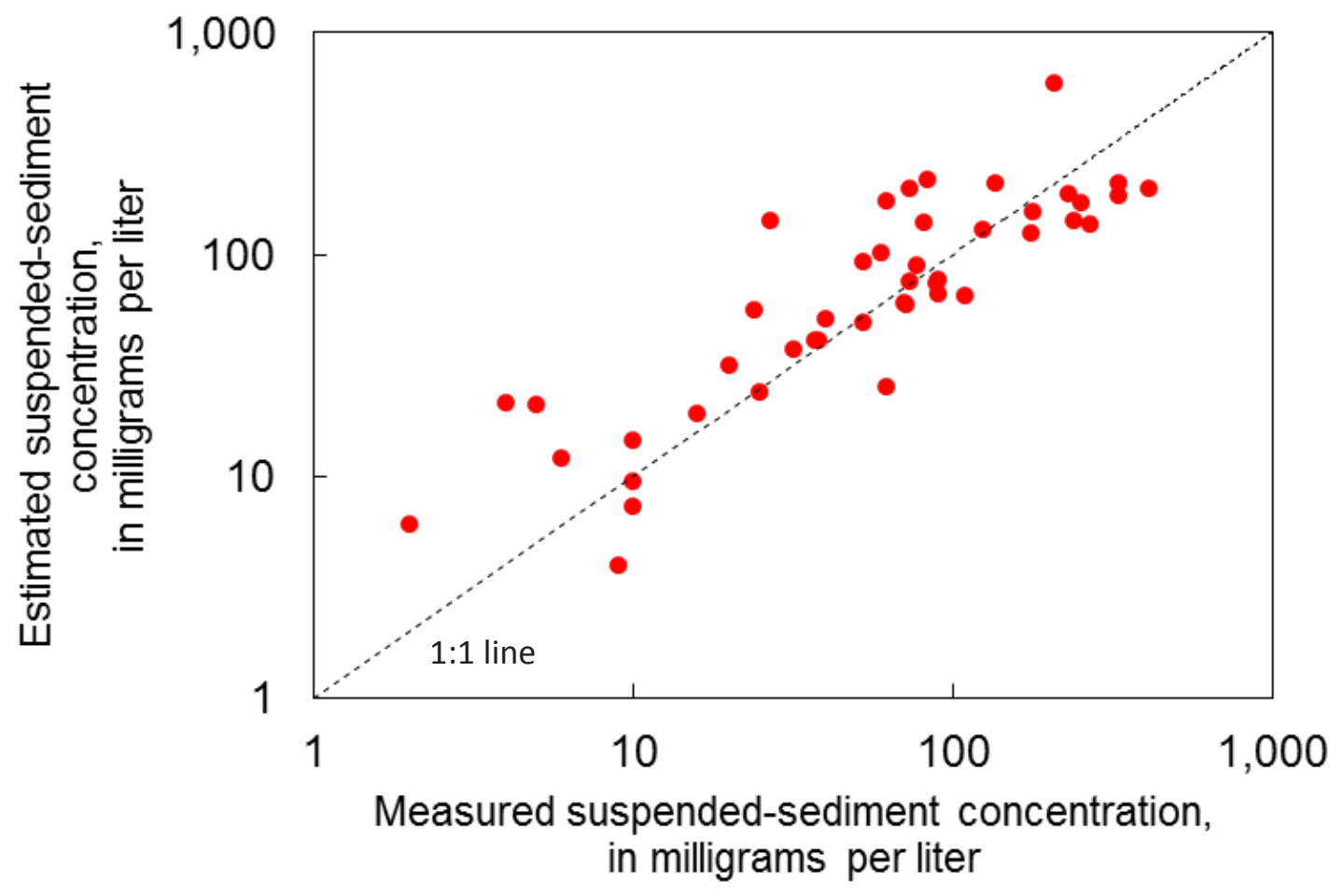

Figure 10. Comparison of measured and estimated concentrations of suspended sediment for samples from the Barton River near Coventry, Vermont, from August 2010 through May 2013. Estimated concentrations are those predicted from the regression model based on sediment-corrected backscatter. 


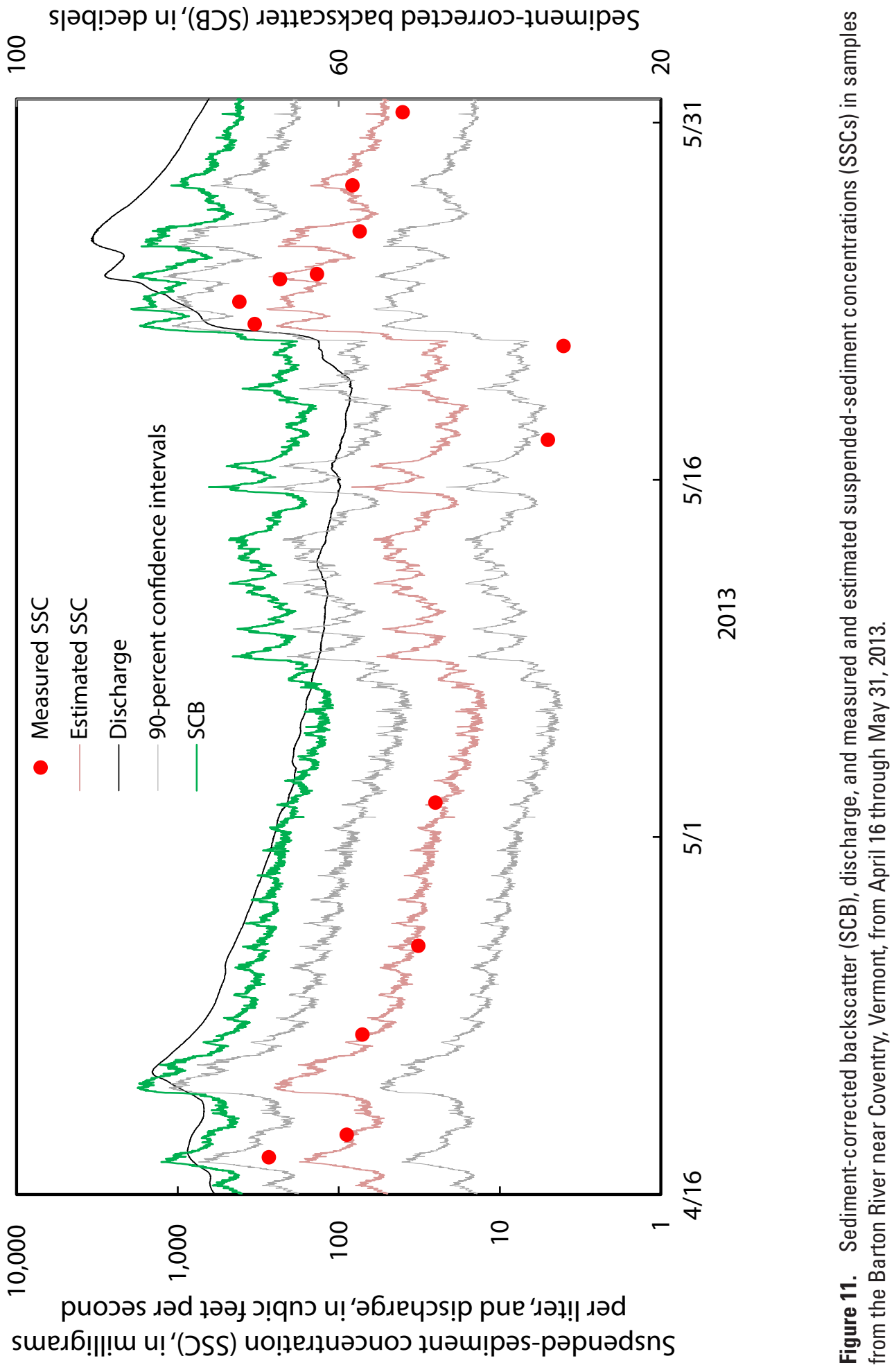




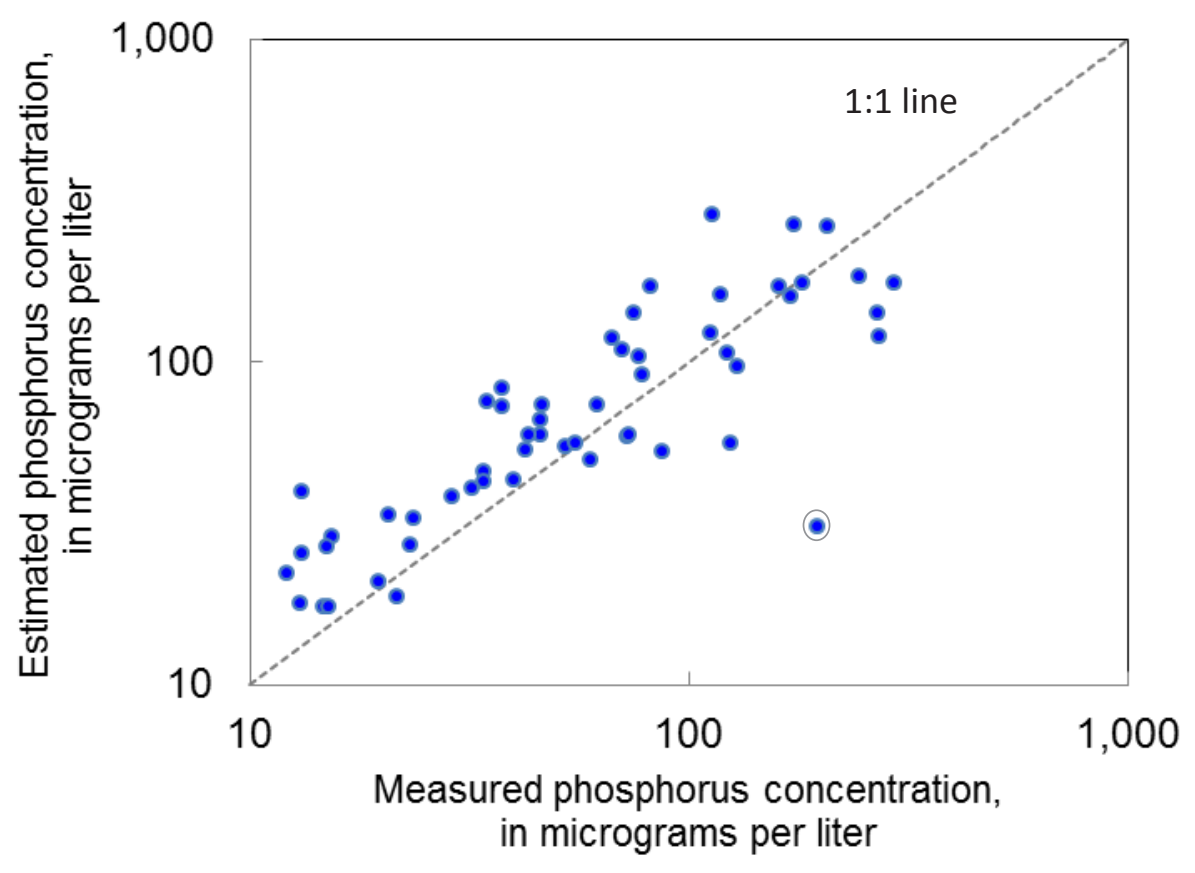

Figure 12. Comparison of measured and estimated concentrations of phosphorus for samples from the Barton River near Coventry, Vermont, from August 2010 through May 2013. Estimated concentrations are those predicted from the regression model based on discharge and hysteresis. Circled point is an unexplained outlier. 

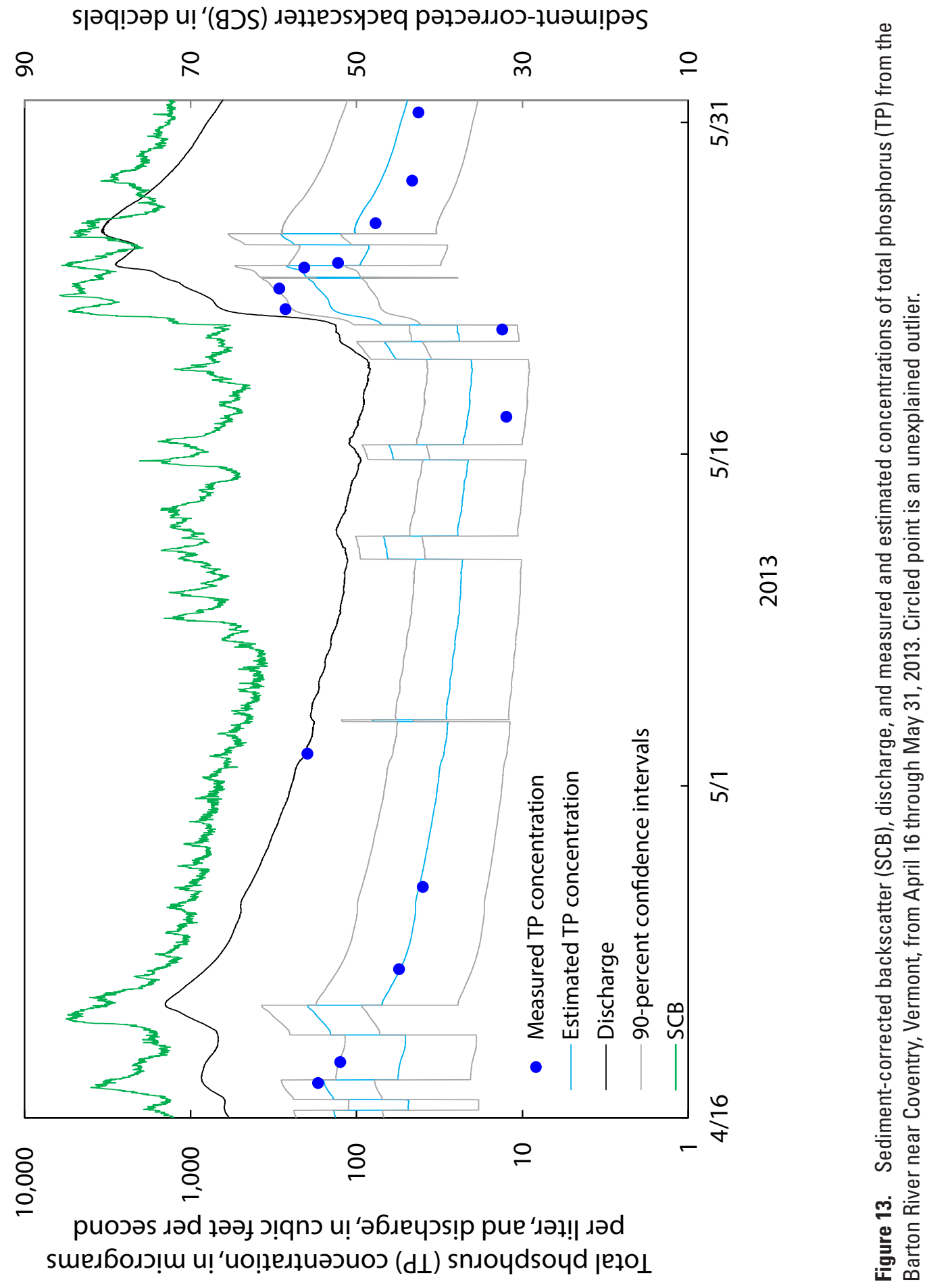
Table 1. Streamflow and concentrations of suspended sediment and phosphorus in water samples from the Barton River near Coventry, Vermont, from 2010 through 2013.

[Fines are less than 0.0625 millimeters and sands are between 0.0625 and 2 millimeters. $\mathrm{N}$, number of samples; $\mathrm{ft}^{3} / \mathrm{s}$, cubic feet per second; $\mathrm{mg} / \mathrm{L}$, milligrams per liter; $\mu \mathrm{g} / \mathrm{L}$, micrograms per liter; \%, percent]

\begin{tabular}{lccccr}
\hline Water property or constituent & Units & $\mathbf{N}$ & Minimum & Median & Maximum \\
\hline Instantaneous discharge & $\mathrm{ft}^{3} / \mathrm{s}$ & 55 & 39 & 719 & 4,550 \\
Fine fraction & $\%$ & 44 & 53 & 80 & 100 \\
Concentration of: & & & & & \\
$\quad$ Suspended sediment & $\mathrm{mg} / \mathrm{L}$ & 46 & 2 & 71 & 413 \\
$\quad$ Total & $\mathrm{mg} / \mathrm{L}$ & 44 & 2 & 52 & 306 \\
$\quad$ Fine-sized & $\mathrm{mg} / \mathrm{L}$ & 44 & 0 & 12 & 107 \\
$\quad$ Sand-sized & $\mu \mathrm{g} / \mathrm{L}$ & 55 & 12 & 55 & 292 \\
$\quad$ Total phosphorus & & & & & \\
\hline
\end{tabular}

Table 2. Coefficients of determination for linear regressions between concentrations of suspended sediment, fines, and sands; and discharge, sediment attenuation, backscatter, and total phosphorus for the Barton River near Coventry, Vermont, from 2010 through 2013.

[p-values for all regression models are less than 0.04. Particle sizes are defined as fines, less than 62.5 micrometers, and sands, between 62.5 micrometers and 2 millimeters. Number of samples with particle-size information was 44 . SSC, suspendedsediment concentration]

\begin{tabular}{lccccc}
\hline \multirow{2}{*}{ Independent variable } & \multicolumn{5}{c}{ Dependent variable, concentrations of } \\
\cline { 2 - 6 } & $\log _{10}$ SSC & Fines & $\log _{10}$ fine & Sand & $\log _{10}$ sand \\
\hline Discharge & 0.27 & 0.09 & 0.18 & 0.29 & 0.35 \\
$\log _{10}$ discharge & 0.57 & 0.16 & 0.45 & 0.32 & 0.57 \\
Sediment-driven acoustic attenuation & 0.43 & 0.22 & 0.37 & 0.45 & 0.57 \\
Backscatter: & & & & & 0.80 \\
$\quad$ Measured & 0.75 & 0.43 & 0.65 & 0.52 & 0.78 \\
$\quad$ Water-corrected & 0.75 & 0.36 & 0.65 & 0.45 & 0.83 \\
$\quad$ Sediment-corrected & 0.77 & 0.39 & 0.65 & 0.54 & 0.53 \\
Total phosphorus & 0.62 & 0.80 & 0.61 & 0.55 & 0.72 \\
$\log _{10}$ total phosphorus & 0.84 & 0.65 & 0.82 & 0.51 & \\
\hline
\end{tabular}


Table 3. Linear regression models and metrics to assess estimated concentrations of suspended sediment and total phosphorus from acoustic surrogates and discharge in the Barton River, Vermont.

[Q or $\log _{10} \mathrm{Q}$ was variously used, depending on which presented the better model fit. No outliers were removed from these regression models. Bold text indicates models used to estimate SSC or TP. Values in gray indicate variables that are not significant $($ at $\alpha=0.1)$ and thus invalid regression models. N, regression number; $\mathrm{r}^{2}$, coefficient of determination; RMSE, root-mean square error; No. of values, number of values used in regression model; $\mathrm{Q}$, discharge; HystQ, marker to indicate position of sample on the hydrograph $(0=$ rising limb and $1=$ falling limb or flat $)$ for potential hysteresis effect; alphaF, fluidabsorption coefficient; alphaS, sediment-driven attenuation coefficient; MB, measured backscatter; WCB, water-corrected backscatter; SCB, sedimentcorrected backscatter; SSC, suspended-sediment concentration; TP, total phosphorus; <, less than]

\begin{tabular}{|c|c|c|c|c|c|c|}
\hline $\mathbf{N}$ & $\begin{array}{l}\text { Independent } \\
\text { variables }\end{array}$ & Regression model & $\mathrm{p}$-value of variables & $r^{2}$ & RMSE & $\begin{array}{l}\text { No. of } \\
\text { values }\end{array}$ \\
\hline \multicolumn{7}{|c|}{ Regressions to estimate concentrations of $\log _{10}$ suspended sediment } \\
\hline 1 & $\log _{10} \mathrm{Q}$ & $\log _{10} \mathrm{SSC}=-0.44+\left(0.78 * \log _{10} \mathrm{Q}\right)$ & $<0.0001$ & 0.57 & 0.37 & 46 \\
\hline 2 & $\log _{10} \mathrm{Q}$, HystQ & $\log _{10} \mathrm{SSC}=0.06+\left(0.73 * \log _{10} \mathrm{Q}\right)-(0.46 *$ HystQ $)$ & $<0.0001,0.0001$ & 0.70 & 0.31 & 46 \\
\hline 3 & alphaF & $\log _{10} \mathrm{SSC}=1.07+(0.86 *$ alphaF $)$ & 0.04 & 0.10 & 0.54 & 45 \\
\hline 4 & alphaS & $\log _{10} \mathrm{SSC}=0.30+(1.31 *$ alphaS $)$ & $<0.0001$ & 0.43 & 0.43 & 45 \\
\hline 5 & MB & $\log _{10} \mathrm{SSC}=-1.87+(0.06 * \mathrm{MB})$ & $<0.0001$ & 0.75 & 0.28 & 45 \\
\hline 6 & $\mathrm{MB}, \log _{10} \mathrm{Q}$ & $\log _{10} \mathrm{SSC}=-1.81+(0.06 * \mathrm{MB})+\left(0.09 * \log _{10} \mathrm{Q}\right)$ & $<0.0001,0.53$ & 0.76 & 0.28 & 45 \\
\hline 7 & MB, HystQ & $\log _{10} \mathrm{SSC}=-1.42+(0.06 * \mathrm{MB})-(0.25 *$ HystQ $)$ & $<0.0001,0.02$ & 0.79 & 0.27 & 45 \\
\hline 8 & MB, alphaF & $\log _{10} \mathrm{SSC}=-1.97+(0.06 * \mathrm{MB})+(0.26 *$ alphaF $)$ & $<0.0001,0.24$ & 0.76 & 0.28 & 45 \\
\hline 9 & WCB & $\log _{10} \mathrm{SSC}=-2.58+(0.06 * \mathrm{WCB})$ & $<0.0001$ & 0.75 & 0.28 & 45 \\
\hline 10 & WCB, Q & $\log _{10} \mathrm{SSC}=-2.57+(0.06 * \mathrm{WCB})+(8.18 \mathrm{e}-07 * \mathrm{Q})$ & $<0.0001,0.99$ & 0.75 & 0.29 & 45 \\
\hline 11 & WCB, HystQ & $\log _{10} \mathrm{SSC}=-2.07+(0.06 * \mathrm{WCB})-(0.25 *$ HystQ $)$ & $<0.0001,0.02$ & 0.78 & 0.27 & 45 \\
\hline 12 & WCB, alphaS & $\log _{10} \mathrm{SSC}=-2.42+(0.05 * \mathrm{WCB})+(0.28 *$ alphaS $)$ & $<0.0001,0.17$ & 0.76 & 0.28 & 45 \\
\hline 13 & SCB & $\log _{10} \mathrm{SSC}=-2.44+(0.05 * \mathrm{SCB})$ & $<0.0001$ & 0.77 & 0.27 & 45 \\
\hline 14 & $\mathrm{SCB}, \mathrm{Q}$ & $\log _{10} \mathrm{SSC}=-2.72+(0.06 * \mathrm{SCB})-(5.61 \mathrm{e}-05 * \mathrm{Q})$ & $<0.0001,0.28$ & 0.77 & 0.27 & 45 \\
\hline 15 & SCB, HystQ & $\log _{10} \mathrm{SSC}=-2.04+(0.05 * \mathrm{SCB})-(0.18 *$ HystQ $)$ & $<0.0001,0.08$ & 0.78 & 0.27 & 45 \\
\hline 16 & SCB, alphaS & $\log _{10} \mathrm{SSC}=-2.53+(0.05 * \mathrm{SCB})-(0.12 *$ alphaS $)$ & $<0.0001,0.61$ & 0.77 & 0.28 & 45 \\
\hline \multicolumn{7}{|c|}{ Regressions to estimate concentrations of $\log _{10}$ phosphorus } \\
\hline 17 & $\log _{10} \mathrm{Q}$ & $\log _{10} \mathrm{TP}=0.23+\left(0.54 * \log _{10} \mathrm{Q}\right)$ & $<0.0001$ & 0.46 & 0.29 & 55 \\
\hline 18 & $\log _{10} Q$, HystQ & $\log _{10} T P=0.84+\left(0.44 * \log _{10} Q\right)-(0.45 *$ HystQ $)$ & $<0.0001,<0.0001$ & 0.70 & 0.22 & 55 \\
\hline 19 & alphaF & $\log _{10} \mathrm{TP}=1.43+\left(0.45^{*}\right.$ alphaF $)$ & 0.07 & 0.06 & 0.39 & 54 \\
\hline 20 & alphaS & $\log _{10} \mathrm{TP}=0.84+\left(0.86^{*}\right.$ alphaS $)$ & $<0.0001$ & 0.37 & 0.32 & 47 \\
\hline 21 & $\mathrm{MB}$ & $\log _{10} \mathrm{TP}=-0.47+(0.04 * \mathrm{MB})$ & $<0.0001$ & 0.53 & 0.27 & 53 \\
\hline 22 & $\mathrm{MB}, \log _{10} \mathrm{Q}$ & $\log _{10} \mathrm{TP}=-0.45+(0.03 * \mathrm{MB})+\left(0.22 * \log _{10} \mathrm{Q}\right)$ & $0.0008,0.08$ & 0.56 & 0.27 & 53 \\
\hline 23 & MB, HystQ & $\log _{10} \mathrm{TP}=0.33+(0.03 * \mathrm{MB})-(0.34 *$ hystQ $)$ & $<0.0001,0.0002$ & 0.65 & 0.24 & 53 \\
\hline 24 & MB, alphaF & $\log _{10} \mathrm{TP}=-0.57+(0.04 * \mathrm{MB})+(0.21 *$ alphaF $)$ & $<0.0001,0.24$ & 0.55 & 0.27 & 53 \\
\hline 25 & WCB & $\log _{10} \mathrm{TP}=-0.93+(0.04 * \mathrm{WCB})$ & $<0.0001$ & 0.54 & 0.27 & 53 \\
\hline 26 & WCB, $\log _{10} \mathrm{Q}$ & $\log _{10} \mathrm{TP}=-0.77+(0.03 * \mathrm{WCB})+\left(0.18 * \log _{10} \mathrm{Q}\right)$ & $0.001,0.17$ & 0.55 & 0.27 & 53 \\
\hline 27 & WCB, HystQ & $\log _{10} \mathrm{TP}=-0.01+(0.03 * \mathrm{WCB})-(0.33 *$ hystQ $)$ & $<0.0001,0.0002$ & 0.65 & 0.24 & 53 \\
\hline 28 & WCB, alphaS & $\log _{10} \mathrm{TP}=-0.64+(0.03 * \mathrm{WCB})+(0.39 *$ alphaS $)$ & $0.0004,0.05$ & 0.53 & 0.28 & 47 \\
\hline 29 & $\mathrm{SCB}$ & $\log _{10} \mathrm{TP}=-0.89+(0.03 * \mathrm{SCB})$ & $<0.0001$ & 0.53 & 0.28 & 47 \\
\hline 30 & $\mathrm{SCB}, \log _{10} \mathrm{Q}$ & $\log _{10} \mathrm{TP}=-0.79+(0.03 * \mathrm{SCB})+\left(0.12 * \log _{10} \mathrm{Q}\right)$ & $0.002,0.44$ & 0.54 & 0.28 & 47 \\
\hline 31 & SCB, HystQ & $\log _{10} \mathrm{TP}=0.03+(0.03 * \mathrm{SCB})-(0.31 *$ hystQ $)$ & $<0.0001,0.002$ & 0.63 & 0.25 & 47 \\
\hline 32 & SCB, alphaS & $\log _{10} \mathrm{TP}=-0.75+(0.03 * \mathrm{SCB})+(0.16 *$ alphaS $)$ & $<0.0001,0.49$ & 0.54 & 0.28 & 47 \\
\hline
\end{tabular}





\section{Appendixes}

[Available separately at http://pubs.usgs.gov/of/2014/1184/]

\section{Appendix 1. Input to Surrogate Analysis and Index Developer Model Program-15-Minute Data on Water Depth and Temperature}

[Appendix is a tab-delimited text file. y, year; m, month; d, day; H, hour; M, minute; S, second; vbeam, water depth in feet; ADVMTemp, temperature in degrees Fahrenheit]

\section{Appendix 2. Input to Surrogate Analysis and Index Developer Model Program-15-Minute Data on Measured Backscatter}

[Appendix is a tab-delimited text file. Cell01SNR1 through Cell05SNR1 represent the signal-to-noise ratios for cells 1 through 5; y, year; m, month; d, day; H, hour; M, minute; S, second]

\section{Appendix 3. Calibration Dataset and Model Results for Streamgage 04296280- Barton River Near Coventry-Suspended-Sediment Concentration}

Appendix 4. Calibration Dataset and Model Results for Streamgage 04296280Barton River Near Coventry-Total Phosphorus Concentration 
Prepared by the Pembroke Publishing Service Center

For more information concerning this report, contact:

Office Chief

New Hampshire-Vermont Office

New England Water Science Center

U.S. Geological Survey

331 Commerce Way, Suite 2

Pembroke, NH 03275

dc_nh@usgs.gov

or visit our Web site at

http://nh.water.usgs.gov 
